\title{
Synaptic Vesicle Endocytosis
}

\author{
Yasunori Saheki and Pietro De Camilli \\ Department of Cell Biology, Howard Hughes Medical Institute and Program in Cellular Neuroscience, \\ Neurodegeneration and Repair, Kavli Institute for Neuroscience, Yale University School of Medicine, \\ New Haven, Connecticut 06510 \\ Correspondence: pietro.decamilli@yale.edu
}

\begin{abstract}
Neurons can sustain high rates of synaptic transmission without exhausting their supply of synaptic vesicles. This property relies on a highly efficient local endocytic recycling of synaptic vesicle membranes, which can be reused for hundreds, possibly thousands, of exoendocytic cycles. Morphological, physiological, molecular, and genetic studies over the last four decades have provided insight into the membrane traffic reactions that govern this recycling and its regulation. These studies have shown that synaptic vesicle endocytosis capitalizes on fundamental and general endocytic mechanisms but also involves neuron-specific adaptations of such mechanisms. Thus, investigations of these processes have advanced not only the field of synaptic transmission but also, more generally, the field of endocytosis. This article summarizes current information on synaptic vesicle endocytosis with an emphasis on the underlying molecular mechanisms and with a special focus on clathrin-mediated endocytosis, the predominant pathway of synaptic vesicle protein internalization.
\end{abstract}

\begin{abstract}
$A^{t}$ synapses, the number of synaptic vesicles Athat undergo exocytosis over a given time period can greatly exceed the supply of synaptic vesicle precursors delivered from the cell body. Thus, nerve terminals have developed efficient endocytic mechanisms to recapture and reuse membranes that have fused with the plasma membrane to release neurotransmitters (Fig. 1A). The occurrence of synaptic vesicle recycling had been inferred early on after the first description of nerve terminal ultrastructure and synaptic vesicles by electron microscopy. However, direct evidence for an endocytic origin of synaptic vesicles was provided by the introduction of extracellular endocytic tracers in the early 1970s (Holtzman et al. 1971). Subsequent electrophysiological studies of stimulated frog
\end{abstract}

neuromuscular junctions in combination with such tracers conclusively established the concept of synaptic vesicle recycling (Ceccarelli et al. 1973; Heuser and Reese 1973). In more recent years, powerful methods have been developed to monitor synaptic vesicle endocytosis and recycling in living neurons. These include imaging methods such as the internalization of fluorescent antibodies directed against luminal epitopes of synaptic vesicles (Matteoli et al. 1992; Kraszewski et al. 1995; Martens et al. 2008), the uptake and release of amphipathic styryl dyes such as FM1-43 (Fig. 1B) (Betz and Bewick 1992), antibodies against luminal domains of synaptic vesicle proteins coupled with $\mathrm{pH}$-sensitive cyanine dye derivative $\mathrm{Cy}$ pHer5E (Hua et al. 2011), and the use of a

Editors: Morgan Sheng, Bernardo Sabatini, and Thomas C. Südhof

Additional Perspectives on The Synapse available at www.cshperspectives.org

Copyright (C) 2012 Cold Spring Harbor Laboratory Press; all rights reserved; doi: 10.1101/cshperspect.a005645

Cite this article as Cold Spring Harb Perspect Biol 2012;4:a005645 


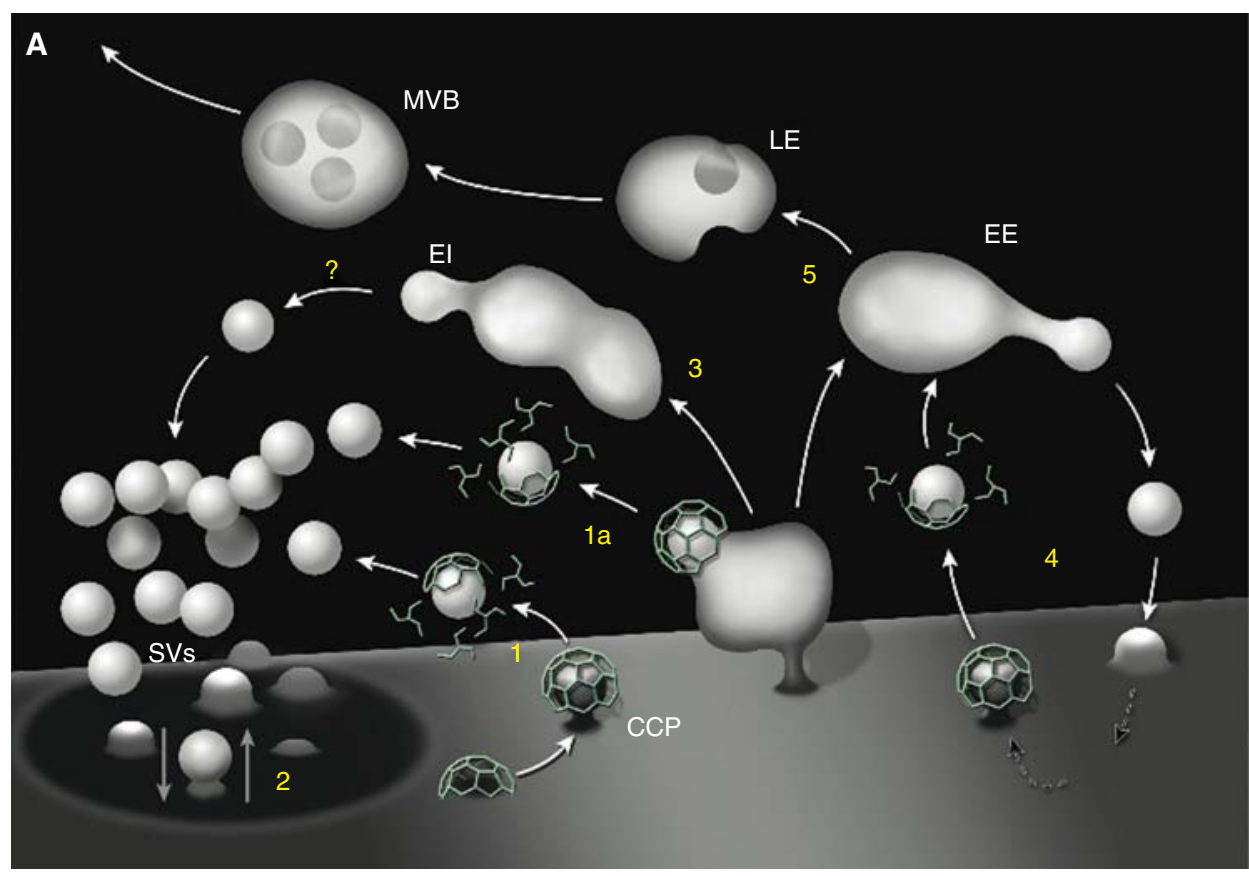

B

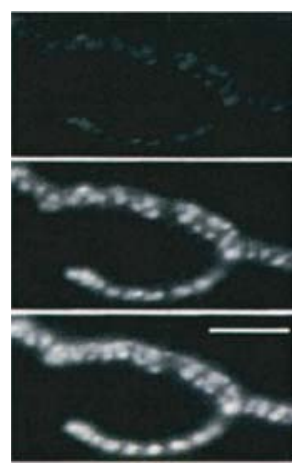

C

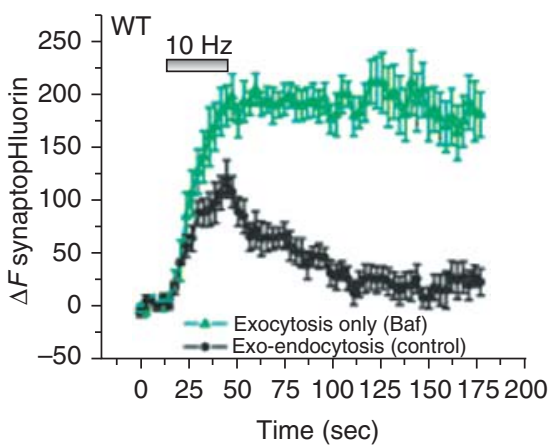

D
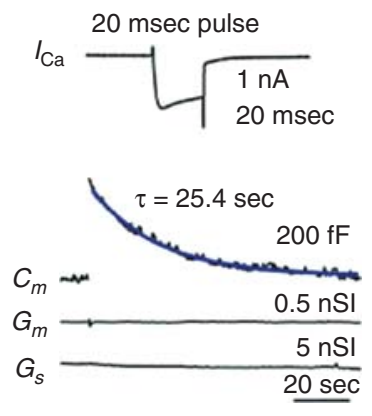

Figure 1. Pathways of synaptic vesicle recycling and examples of methods to monitor synaptic vesicle endocytosis at living synapses. (A) Schematic diagram of membrane traffic in axon terminals illustrating endocytosis of synaptic vesicle (SV) membranes via clathrin-coated pits (CCP) from the plasma membrane and its deep infoldings (1 and 1a), "kiss and run" (2), and bulk endocytosis (3) followed by vesicle formation via unknown mechanisms (?) from endocytic intermediates (EI). This recycling traffic is interconnected with housekeeping membrane recycling (4) involving clathrin-mediated endocytosis and canonical early endosomes (EE) as well as with traffic to the cell body (5) via late endosomes (LE) and multivesicular bodies (MVBs). (B) Compensatory endocytosis of synaptic vesicle membranes at the frog neuromuscular junction following stimulation by depolarization in high potassium, visualized by the uptake of the fluorescent styryl dye FM1-43. Partial and full dye loading are shown in the middle and lower panels (Panel $B$ is from Betz and Bewick 1992; reprinted, with permission, from Science (C) 1992). (C) Time course of exo- and endocytosis in response to a 10-Hz, 30-sec stimulus at synapses of cultured mouse cortical neurons as monitored by the increase and decrease in the fluorescence of synaptopHluorin $(\mathrm{spH})$, a fusion protein of pHluorin to synaptobrevin/VAMP2. Bafilomycin (Baf), a membrane-permeable blocker of the $\mathrm{V}$-type ATPase that is required for vesicle reacidification, was used to trap vesicles at neutral $\mathrm{pH}$ after endocytosis, thus allowing $\mathrm{spH}$ to remain fluorescent even after endocytosis. Control runs (black) consist of the sum of exo- and endocytosis, and Baf runs (green) monitor all the exocytic events. (See facing page for legend.) 
$\mathrm{pH}$-sensitive green fluorescent protein (GFP) (pHluorin) fused to luminal domains of synaptic vesicle proteins (Fig. 1C). Given the low $\mathrm{pH}$ of the synaptic vesicle lumen and the very rapid reacidification of vesicles after endocytosis, pHluorin's fluorescence monitors the shuttling of vesicle proteins to and from the neutral environment of the extracellular medium (Miesenbock et al. 1998; Sankaranarayanan and Ryan 2000). An additional method that has an exquisite temporal resolution, but can only be reliably applied to large nerve terminals, is the electrophysiological recording of changes in plasma membrane capacitance resulting from exoendocytosis (Fig. 1D) (Neher and Marty 1982; von Gersdorff and Matthews 1994; Sun and Wu 2001; Wu and Wu 2007; Lou et al. 2008). Collectively, these techniques have greatly helped elucidate mechanisms and kinetic parameters of synaptic vesicle endocytosis.

The time course of endocytosis varies at different synapses and with the intensity of stimulation. Endocytic styryl dyes, applied in a pulsechase manner after electrical stimulation, revealed that membrane recovery after an exocytic burst (e.g., $20-100$ action potentials at $20 \mathrm{~Hz}$ at hippocampal synapses in culture or $10 \mathrm{sec}$ at $30 \mathrm{~Hz}$ at the frog neuromuscular junction) required less than $1 \mathrm{~min}$ to complete and had a time constant in the range of 20-30 sec (Ryan et al. 1996; Wu and Betz 1996), similar to what had been predicted by earlier morphological experiments (Miller and Heuser 1984). Realtime measurements of endocytosis by the use of pHluorin confirmed that the average time constant of endocytosis is in the range of 15$20 \mathrm{sec}$ when the system is not saturated (e.g., 50 action potentials at $10 \mathrm{~Hz}$ ) and subsequent studies strongly suggested that under these conditions the endocytic process is dependent on the clathrin coat (Granseth et al. 2006; Balaji and Ryan 2007; Kim and Ryan 2009). At high levels of activity the endocytic rate slows down, indicating that under these conditions the surface accumulation of synaptic vesicle membranes (the exocytic load) exceeds the endocytic capacity (Sankaranarayanan and Ryan 2000; Granseth et al. 2006; Balaji et al. 2008).

Measurements of the endocytic recovery of synaptic vesicle membranes by capacitance recording in frog saccular hair cells, axon terminals of goldfish bipolar neurons, and calyx of Held synapses showed time scales in a similar range and a longer time course after a strong exocytic load (Fig. 1D) (Parsons et al. 1994; von Gersdorff and Matthews 1994; Sun and Wu 2001; Sun et al. 2002; Wu et al. 2005). These studies also revealed the existence of an additional fast kinetic component of endocytosis $(\sim 1 \mathrm{sec})$, which has been proposed to be mediated by a distinct molecular mechanism (von Gersdorff and Matthews 1994; Neves et al. 2001; Hull and von Gersdorff 2004; Jockusch et al. 2005).

It should be noted that most of these studies have investigated time course of endocytosis after a burst of exocytic events. It remains possible that the compensatory endocytic reaction after a single stimulus may be even faster.

\section{PATHWAYS OF ENDOCYTOSIS}

The precise pathways taken by synaptic vesicle membranes during their endocytic recycling have been and continue to be an object of debate. This debate has been fueled, in part, by the remarkable plasticity of endocytic traffic in nerve terminals. Although the exo-endocytosis that occurs at rest (the events responsible for miniature synaptic currents), or during modest activity,

Figure 1. (Continued) The difference between the two traces allows estimating total endocytosis occurring during the experiment. (Panel $C$ is from Nicholson-Tomishima and Ryan 2004; reprinted, with permission, from Proc Natl Acad Sci (C) 2004.) (D) Endocytic recovery of the increase in surface area produced by a secretory burst at a calyx of Held giant nerve terminal as monitored by the measurement of membrane capacitance ( $C_{m}$, blue trace). Secretion was evoked by a single $20-\mathrm{msec}(+10 \mathrm{mV})$ presynaptic pulse that elicited the $\mathrm{Ca}^{2+}$ current shown in the top trace. Membrane conductance $\left(G_{m}\right)$ and series conductance $\left(G_{s}\right)$ did not change during the recording. (Panel $D$ is from Lou et al. 2008; reprinted, with permission, from the author.) 
does not involve major structural perturbations of nerve terminals, intense activity induces major and reversible structural changes that vary dependent on the type of stimulation (Ceccarelli et al. 1973; Miller and Heuser 1984; Heuser 1989; Holt et al. 2003; Teng et al. 2007; Clayton et al. 2008; Hayashi et al. 2008). A variety of endocytic intermediates have been observed by electron microscopy under these conditions (Heuser and Reese 1973), and it has been difficult to reconcile all these observations into a simple unifying model. Likewise, studies of endocytic membrane recovery using membrane capacitance methods or dynamic fluorescence imaging have suggested multiple modes of endocytosis (Smith et al. 2008). Importantly, it has been difficult to correlate some of the observations obtained by imaging and electrophysiology with results of electron microscopy. Furthermore, although much has been learned about the endocytosis of individual small vesicles by live imaging in nonneuronal cells, for technical reasons this has not been possible yet for nerve terminals, given their very small size. However, some major concepts have emerged.

There is compelling evidence for the importance of clathrin-mediated endocytosis in the internalization of synaptic vesicle proteins and also strong evidence for the hypothesis that synaptic vesicles derive directly from the uncoating of clathrin-coated vesicles (Fig. 1A, and see below). However, clathrin may not be absolutely essential for synaptic vesicle reformation, as a recent study in Caenorhabditis elegans has suggested (Sato et al. 2009). Clearly, in response to a very strong exocytic burst, a different endocytic mechanism, called bulk endocytosis, comes into play. Bulk endocytosis leads to the generation of endocytic vacuoles that are subsequently converted into synaptic vesicles by a mechanism that remains elusive (Fig. 1A) (Miller and Heuser 1984; Holt et al. 2003; Paillart et al. 2003; Wu and Wu 2007; Hayashi et al. 2008; Meunier et al. 2010). A third form of endocytosis, the rapid closure of a fusion pore without collapse of the vesicle, termed "kiss and run," remains an attractive model to explain electrophysiological and dynamic imaging data that are difficult to reconcile with other endocytic mechanisms (Fig. 1A)
(Ceccarelli et al. 1973; Fesce et al. 1994; Klyachko and Jackson 2002; Aravanis et al. 2003; Harata et al. 2006; He et al. 2006; Zhang et al. 2009).

These pathways are discussed below with major emphasis on clathrin-dependent synaptic vesicle reformation given the evidence for the importance of this process at synapses and the substantial mechanistic understanding that has been reached for this form of endocytosis.

\section{CLATHRIN-MEDIATED ENDOCYTOSIS}

The role of clathrin-mediated endocytosis in the recycling of synaptic vesicles has been supported by many different experimental approaches. (1) Induction of a burst of exocytosis results in a transient accumulation of clathrincoated endocytic intermediates (Heuser and Reese 1973; Gad et al. 1998). (2) Experimental manipulations of synapses known to block clathrin-mediated endocytosis result in a block of synaptic vesicle recycling (Shupliakov et al. 1997; Zhang et al. 1998; Ringstad et al. 1999; Morgan et al. 2000; Granseth et al. 2006; Ferguson et al. 2007; Heerssen et al. 2008; Kasprowicz et al. 2008; Kim and Ryan 2009; von Kleist et al. 2011). (3) Conversely, many perturbations that block synaptic vesicle recycling result in a major buildup of clathrin-coated intermediates (Shupliakov et al. 1997; Cremona et al. 1999; Ferguson et al. 2007; Hayashi et al. 2008; Milosevic et al. 2011; Raimondi et al. 2011). (4) Synaptic vesicle proteins represent the main cargo of purified brain clathrin-coated vesicles (Maycox et al. 1992; Blondeau et al. 2004). Indeed, the abundance at clathrin-mediated endocytosis at synapses has made brain the tissue of choice for the purification of clathrin-coated vesicles (Kadota and Kadota 1973; Pearse 1975).

\section{CLATHRIN COATS AND THE GENESIS OF A SYNAPTIC VESICLE}

Textbook diagrams often show that the fate of presynaptic clathrin-coated vesicles after their uncoating is to fuse with early endosomes, which then function as the source of new synaptic vesicles (Heuser and Reese 1973; Mellman 1996). This model, which fits with the typical 
fate of clathrin-coated vesicles in other systems, was first suggested at the time when the coatdependent synaptic vesicle recycling was first characterized (Heuser and Reese 1973). At the time, coated buds on cisternae not connected to the cell surface in the plane of the section were interpreted as coated vesicles in the process of fusion (Heuser and Reese 1973). However, subsequent studies showed that clathrin-coated vesicles rapidly uncoat after fission (Guan et al. 2010; Milosevic et al. 2011) and that even coated buds located deep in nerve terminals represent budding from plasma membrane invaginations rather than fusion events (Ferguson et al. 2007; Hayashi et al. 2008; Raimondi et al. 2011). Based on these considerations, the direct reformation of synaptic vesicles from the uncoating of clathrin-coated vesicles, as suggested by Figure 1A, was proposed (Takei et al. 1996). According to this second model, at least many of the large and numerous endocytic intermediates observed in nerve terminals after strong stimulation are not stations downstream from clathrin-coated vesicles, but vacuoles that result from the bulk uptake of excess membrane (bulk endocytosis).

This model is attractive for several reasons. First, studies of vesicle formation in a variety of organisms and at different stations of the exoand endocytic pathways have established that "coat"-mediated budding is a general mechanism for the production of vesicles with a precise molecular composition because of the property of coats to act as molecular sorters (Rothman 1994; Bednarek et al. 1996). Components of the endocytic clathrin coat, along with their accessory factors, are the major coat proteins concentrated in nerve terminals, strongly implicating them in the formation of synaptic vesicles (Maycox et al. 1992; Ferguson et al. 2007). Second, the model eliminates the requirement for two distinct budding steps in the recycling of synaptic vesicles-a first clathrin-mediated budding from the plasma membrane followed by a second budding reaction from endosomes - and thus is more compatible with the fast time course of this process. Third, clathrin-coated pits of nerve terminals have a remarkably small and homogeneous size, in the same range of the size of synaptic vesicles (Shupliakov et al. 1997; Raimondi et al. 2011). This characteristic, which contrasts with the heterogeneous size of clathrin-coated buds observed in other systems and even in neurons away from presynaptic sites, is consistent with a direct formation of synaptic vesicles from clathrin-coated vesicles that have shed their coats. Fourth, a scenario in which clathrin-coated vesicles are directly upstream of synaptic vesicles is supported by quantal analysis studies of the uptake and release of styryl dyes (Ryan et al. 1997; Murthy and Stevens 1998).

Some general principles apply to clathrinmediated endocytosis in all cellular contexts (Conner and Schmid 2003; Jung and Haucke 2007; Dittman and Ryan 2009; Kirchhausen 2009; McMahon and Boucrot 2011; Taylor et al. 2011). The nucleation of a clathrin-coated pit starts with the interaction of clathrin adaptors and/or a subset of their accessory factors with the lipid bilayer and with membrane proteins. In this nucleation stage, obligatory intrinsic components of the vesicle membrane (Koo et al. 2011; Miller et al. 2011), such as those that direct vesicle traffic, are likely to play a dominant role. Subsequently, interactions of the adaptors with each other, with other accessory factors, with cargo proteins, and with clathrin lead to the rapid growth of the coat in a feed-forward, cooperative fashion. Eventually, a deeply invaginated clathrin-coated bud with a narrow neck is formed. Fission of this neck in a reaction that requires the GTPase dynamin (Koenig and Ikeda 1989; Conner and Schmid 2003; Ferguson and De Camilli 2012) leads to a free vesicle that rapidly uncoats.

However, in axon terminals, clathrin-mediated endocytosis has some unique properties. These include, besides the highly homogeneous small size of the vesicles, specificity of the cargo and speed of the process. Because synaptic vesicles have a very precise function, mechanisms must exist to mediate the inclusion into the nascent vesicle of all needed membrane proteins and in the appropriate stoichiometry relative to each other. For example, although some proteins (such as synaptobrevin/VAMP) are present in tens of copies, others are present in few, or 
even single copies (e.g., neurotransmitter transporters and the vacuolar ATPase) (Takamori et al. 2006), suggesting the existence of a checkpoint to ensure that all critical components are on board. Little is known about these mechanisms. Given the special nature of clathrinmediated endocytosis at synapses, several endocytic factors that play general roles in endocytosis are present at synapses as neuron-specific isoforms. An overview of clathrin-dependent endocytosis in presynaptic nerve terminals is presented below.

\section{CORE COMPONENTS AND ACCESSORY FACTORS OF THE CLATHRIN COAT}

Like other coats, the clathrin coat is composed of two layers: an inner layer of adaptors and an outer clathrin layer (Table 1). The clathrin adaptors typically comprise a membrane-binding folded module and flexible arms, which may terminate in an additional small folded module (ear) (Edeling et al. 2006). The folded module binds cytoplasmically exposed domains or endocytic "motifs" of vesicle membrane proteins as well as the head group of $\mathrm{PI}(4,5) \mathrm{P}_{2}$, a phosphoinositide concentrated in the plasma membrane (Beck and Keen 1991; Traub 2003; Owen et al. 2004; Zoncu et al. 2009; Jackson et al. 2010). The arms bind clathrin heavy chain as well as other adaptors and endocytic factors (Edeling et al. 2006; Schmid and McMahon 2007). Their elongated flexible unfolded structure is optimally suited to capture these proteins in the cytosol and to help concentrate them at growing coated buds.

The most abundant adaptor is AP-2, a member of a heterotetrameric family of adaptors that interacts with tyrosine-based endocytic motifs (Bonifacino and Traub 2003), such as the one present in the synaptic vesicle protein SV2 (Haucke and De Camilli 1999), and with dileucine-based motifs, such as those in vesicular neurotransmitter transporters (Bonifacino and Traub 2003; Fei et al. 2008). The other major synaptic endocytic clathrin adaptor is the ANTH domain-containing protein AP180 (Morgan et al. 2000; Ford et al. 2001), which like its nonsynaptic homolog CALM (clathrin assembly lymphoid myeloid leukemia) binds the V-SNARE synaptobrevin/VAMP (Nonet et al. 1999; Dittman and Kaplan 2006; Burston et al. 2009; Koo et al. 2011; Miller et al. 2011). Yet another adaptor is stonin 2, that along with AP-2 plays a role in the internalization of synaptotagmin, the $\mathrm{Ca}^{2+}$ sensor of the synaptic vesicle (Zhang et al. 1994; Walther et al. 2001, 2004; Diril et al. 2006). Epsin is a clathrin adaptor that binds ubiquitinated cargo and may have additional function in endocytosis (Ford et al. 2002; Boucrot et al. 2012), but the importance of its function in synaptic vesicle endocytosis remains unclear (De Camilli et al. 2002; Ford et al. 2002). FCHo, a protein that comprises an F-BAR domain (see below) and a domain homologous to a cargobinding subunit of AP-2, may also have adaptor functions for a yet to be determined cargo. Several other proteins with endocytic adaptor properties (also called CLASP for clathrincoat-associated sorting proteins) (Mishra et al. 2005) have been identified; for example, Dab (Morris and Cooper 2001), ARH (He et al. 2002), $\beta$-arrestin (Lin et al. 1997), etc. However, so far these proteins have not been shown to play a major role in synaptic vesicle recycling.

The clathrin lattice is represented by a chicken-wire-like structure that results from the assembly of clathrin triskelia (trimers of clathrin heavy chains with three bound light chains) (Kirchhausen 2000a). Clathrin, which can assemble with various geometries and forms basketlike structures in the absence of a membrane template, had been assumed to be the primary determinant of membrane curvature. However, current models posit that clathrin adapts to, and stabilizes, membrane curvature induced by other factors (the adaptors and its accessory factors), although it may cooperate in propagating curvature once a bud has been nucleated (Ford et al. 2002; Itoh and De Camilli 2006) (see also below). Clathrin also functions as a scaffold for the clustering of the adaptors and thus of membrane cargo to be internalized.

In addition to the core components of the coat, i.e., the adaptors and clathrin, several factors that assist and/or regulate the nucleation, loading, and dynamics of endocytic clathrincoated pits were identified through biochemical 
Table 1. Major endoytic proteins implicated in synaptic vesicle recycling

\begin{tabular}{|c|c|c|c|}
\hline Protein & Major binding partners & Function & $\begin{array}{l}\text { Genetic } \\
\text { evidence }\end{array}$ \\
\hline \multicolumn{4}{|c|}{ Core clathrin coat components } \\
\hline $\begin{array}{l}\text { Clathrin (heavy } \\
\text { and light chain) }\end{array}$ & $\begin{array}{l}\text { AP-2, AP180/CALM, Epsin, } \\
\text { Amphiphysin, Synaptojanin, } \\
\text { Hsc70, Auxilin }\end{array}$ & Clathrin lattice & + \\
\hline $\begin{array}{l}\text { AP-2 } \\
\text { (heterotetramer } \\
\text { of } \alpha, \beta, \gamma, \delta \\
\text { subunits) }\end{array}$ & $\begin{array}{l}\text { Clathrin, Epsin, AP180/CALM, } \\
\text { Stonin, Amphiphysin, } \\
\text { Synaptojanin, PIPK1 } \gamma \text {, Intersectin, } \\
\text { Eps15, Auxilin, Synaptotagmin, } \\
\text { SV2, PI }(4,5) \mathrm{P}_{2}\end{array}$ & $\begin{array}{l}\text { Clathrin adaptor for several proteins } \\
\text { of vesicle membranes }\end{array}$ & + \\
\hline AP180/CALM & $\begin{array}{l}\text { AP-2, Clathrin, VAMP/ } \\
\text { Synaptobrevin, } \mathrm{PI}(4,5) \mathrm{P}_{2}\end{array}$ & $\begin{array}{l}\text { Specific clathrin adaptor for VAMP/ } \\
\text { Synaptobrevin }\end{array}$ & + \\
\hline Epsin & $\begin{array}{l}\text { AP-2, Clathrin, Intersectin, Eps15, } \\
\text { EHD, ubiquitin, } \mathrm{PI}(4,5) \mathrm{P}_{2}\end{array}$ & $\begin{array}{l}\text { Clathrin adaptor, specific adaptor for } \\
\text { ubiquitinated membrane proteins, } \\
\text { role in bilayer deformation and } \\
\text { fission }\end{array}$ & + \\
\hline Stonin & $\begin{array}{l}\text { AP-2, Intersectin, Eps } 15, \\
\quad \text { Synaptotagmin, } \mathrm{PI}(4,5) \mathrm{P}_{2}\end{array}$ & $\begin{array}{l}\text { Specific clathrin adaptor for } \\
\text { synaptotagmin }\end{array}$ & + \\
\hline \multicolumn{4}{|c|}{ BAR domain-containing proteins (generate/sense bilayer curvature) } \\
\hline Endophilin & Dynamin, Synaptojanin & $\begin{array}{l}\text { Coordinates curvature acquisition } \\
\text { with fission and uncoating of } \\
\text { clathrin-coated vesicles }\end{array}$ & + \\
\hline Amphiphysin & $\begin{array}{l}\text { AP-2, Clathrin, Dynamin, } \\
\text { Synaptojanin, Endophilin, } \\
\text { N-WASP }\end{array}$ & $\begin{array}{l}\text { Coordinates curvature acquisition } \\
\text { with fission? }\end{array}$ & + \\
\hline FCHo & Intersectin, Eps15, Dynamin & $\begin{array}{l}\text { Key nucleator of endocytic clathrin- } \\
\text { coated pits, cargo binding? }\end{array}$ & a \\
\hline Syndapin & $\begin{array}{l}\text { Dynamin, Synaptojanin, EHD, } \\
\text { N-WASP }\end{array}$ & $\begin{array}{l}\text { Coordinates endocytosis with actin } \\
\text { nucleation }\end{array}$ & + \\
\hline Nervous wreck & Dynamin, Intersectin, N-WASP & Implicated in actin assembly & + \\
\hline Toca/Fbp17/CIP4 & Dynamin, N-WASP & $\begin{array}{l}\text { Implicated in actin cytoskeleton } \\
\text { nucleation and organization }\end{array}$ & $\mathrm{a}$ \\
\hline \multicolumn{4}{|c|}{ Phosphoinositide metabolism } \\
\hline $\begin{array}{l}\text { Synaptojanin } 1 \\
\text { (145 kDa } \\
\text { isoform) }\end{array}$ & $\begin{array}{l}\text { AP-2, Clathrin, Endophilin, } \\
\text { Amphiphysin, Syndapin, } \\
\text { Intersectin }\end{array}$ & $\begin{array}{l}\mathrm{PI}(4,5) \mathrm{P}_{2} \text { phosphatase that couples } \\
\text { fission of clathrin-coated vesicles } \\
\text { to the shedding of the adaptors } \\
\text { during uncoating }\end{array}$ & + \\
\hline PIPK1 $\gamma$ & AP-2, Talin 2 & $\begin{array}{l}\text { Major } \mathrm{PI}(4,5) \mathrm{P}_{2} \text { synthesizing enzyme } \\
\text { at the presynaptic plasma } \\
\text { membrane }\end{array}$ & + \\
\hline \multicolumn{4}{|l|}{ Scaffolding } \\
\hline Intersectin & $\begin{array}{l}\text { AP-2, Epsin, Stonin, FCHo, Eps15, } \\
\text { Dynamin, Synaptojanin, N-WASP, } \\
\text { Cdc42 (GEF for Cdc42) }\end{array}$ & $\begin{array}{l}\text { Scaffolding proteins that coordinate } \\
\text { the recruitment of a multiplicity of } \\
\text { other factors }\end{array}$ & + \\
\hline Eps15 & AP-2, Intersectin, Stonin, Epsin & & + \\
\hline Tuba/DNMBP & $\begin{array}{l}\text { Dynamin, N-WASP, Ena/VASP, WAVE } \\
\text { complex, Cdc42 (GEF for Cdc42) }\end{array}$ & & a \\
\hline
\end{tabular}


Y. Saheki and P. De Camilli

Table 1. Continued

\begin{tabular}{|c|c|c|c|}
\hline Protein & Major binding partners & Function & $\begin{array}{l}\text { Genetic } \\
\text { evidence }\end{array}$ \\
\hline \multicolumn{4}{|c|}{ Membrane fission } \\
\hline Dynamin & $\begin{array}{l}\text { Endophilin, Amphiphysin, Tuba/ } \\
\text { DNMBP, Syndapin, Nervous } \\
\text { wreck, Toca/Fbp17/CIP4, } \\
\text { Intersectin, Cortactin, F-actin }\end{array}$ & $\begin{array}{l}\text { GTPase required for endocytic } \\
\text { membrane fission }\end{array}$ & + \\
\hline \multicolumn{4}{|c|}{ Clathrin lattice disassembly } \\
\hline $\mathrm{Hsc} 70$ & Auxilin, Clathrin & $\begin{array}{l}\text { ATPase that triggers disassembly of } \\
\text { clathrin cages }\end{array}$ & + \\
\hline Auxilin & Clathrin, AP-2, Dynamin & $\begin{array}{l}\text { Cofactor of } \mathrm{Hsc} 70 \text { that recruits } \mathrm{Hsc} 70 \\
\text { to clathrin-coated vesicles }\end{array}$ & + \\
\hline
\end{tabular}

${ }^{\text {a }}$ Likely play a role in synaptic vesicle recycling but genetic evidence is still missing.

and genetic screens (Slepnev and De Camilli 2000; Toret and Drubin 2006; Dittman and Ryan 2009; McPherson 2010). Some of these proteins, collectively referred to as clathrin accessory factors (Slepnev and De Camilli 2000), may in fact be considered core components of the coat (Table 1). Typically they contain protein-protein or protein-lipid interacting modules as well as extended regions harboring short amino acid sequence motifs that mediate additional intra- or intermolecular interactions. Thus, they are optimally suited to assemble protein networks. Modules often present in such factors include $\mathrm{SH} 3$ domains, BAR domains, ENTH/ANTH and PH domains, whereas short amino acid motifs include prolinecontaining motifs (for $\mathrm{SH} 3$ domain binding), NPF motifs (for EH domain binding), clathrin boxes (for clathrin binding), and several motifs that recognize the appendage domains of the clathrin adaptor AP-2 (DPF/DPW, FXDXF, WXXF) (Slepnev and De Camilli 2000; Dittman and Ryan 2009; McPherson 2010). Some of these accessory factors contain enzymatic modules such as protein kinases (for example, Ack and AAK1 [Conner and Schmid 2002; Shen et al. 2010], phosphoinositide-metabolizing enzymes [McPherson et al. 1996; Thieman et al. 2009; Kahlfeldt et al. 2010], and DENN domains, i.e., modules that function as guanylnucleotide exchange factors for Rab proteins [Marat et al. 2010; Wu et al. 2011]). Ubiquitin and ubiquitin-binding motifs are also present in some accessory factors (Slepnev and De Camilli 2000; De Camilli et al. 2002; Polo et al. 2003; Itoh and De Camilli 2006; Dittman and Ryan 2009). Overall, the relatively low affinity involved in the interactions mediated by these modules and motifs (low micromolar range) in clathrin accessory factors is ideally suited to allow the rapid formation and disassembly of molecular networks. The functional characterization of these proteins has generated many insights into the formation and maturation of clathrin-coated vesicles. Some themes that have emerged from the studies of these proteins are discussed below.

\section{CURVATURE GENERATION AND CURVATURE SENSING}

Several proteins associated with coats were assigned functions in curvature acquisition and/ or curvature sensing (Table 1). The formation of a high-curvature bud requires the existence of mechanisms that counteract the spontaneous tendency of a phospholipid bilayer to adopt a flat shape. Curvature can be induced by the generation of asymmetries between the two leaflets of the bilayer, by curved protein scaffolds that directly or indirectly bind the bilayer, or by cytoskeletal elements that act on the membrane (Farsad and De Camilli 2003). All these sets of 
factors may come into play in the formation of clathrin-coated vesicles. (1) Some endocytic proteins contain amphipathic helices that partially penetrate the cytosolic leaflet of the bilayer, thus generating bilayer asymmetry (Farsad et al. 2001; Ford et al. 2002; Gallop et al. 2006; Masuda et al. 2006; Antonny 2011). (2) Other endocytic factors contain curved lipid-binding domains of the BAR superfamily (narrow curvature in the classical BAR domains, shallow curvature in the F-BAR domains) (Peter et al. 2004; Weissenhorn 2005; Shimada et al. 2007; Frost et al. 2008). BAR domains form homo or heterodimers whose concave, positively charged surface (in the case of BAR domain-containing proteins implicated in endocytosis) is optimally adapted to interact with a curved, negatively charged bilayer surface (Frost et al. 2009). (3) Still other factors are actin regulatory proteins that can produce curvature indirectly, via the force applied to membranes by the actin cytoskeleton (Kaksonen et al. 2006; Ferguson et al. 2009), as further discussed below.

Importantly, protein modules that can induce curvature can also sense curvature and bind more efficiently to a precurved bilayer (Antonny 2006; Roux et al. 2010), so that curvature can be rapidly propagated by these modules (Takei et al. 1999; Farsad et al. 2001; Itoh et al. 2005; Tsujita et al. 2006; Frost et al. 2008). Furthermore, curvature sensing by proteins that contain other functional domains represents a powerful mechanism to coordinate progressive acquisition of membrane curvature with changes that must occur at various stages of maturation of the coated pit (Dawson et al. 2006; Itoh and De Camilli 2006).

Although there is evidence that these various mechanisms play an important role in curvature acquisition and sensing in clathrin-mediated endocytosis, the precise identity and relative importance of the specific factors implicated in shape changes of presynaptic clathrincoated pits remain poorly understood. Based on in vitro studies, epsin, which shares properties of adaptors, was proposed to function as a critical determinant of endocytic clathrin-coated pit curvature via its amino-terminal amphipathic helix that folds uon $\mathrm{PI}(4,5) \mathrm{P}_{2}$ binding
(Ford et al. 2002). A role of epsin in clathrindependent synaptic vesicle recycling is supported by antibody-microinjection studies in the lamprey giant axon (Jakobsson et al. 2008), and indirectly by the reported role in this process of its $\mathrm{EH}$ domain-containing binding partners Eps15, intersectin, and EHD (Salcini et al. 2001; Marie et al. 2004; Montesinos et al. 2005; Rose et al. 2007; Ko et al. 2010; Pechstein et al. 2010a,b; Jakobsson et al. 2011), but not yet by genetic studies in model organisms (Bao et al. 2008; Chen et al. 2009). It remains possible that a function of epsin in curvature generation, or even in membrane fission, as recently proposed (Boucrot et al. 2012) may be nonessential and redundant with that of other endocytic factors. Endophilin, which contains both a BAR domain and amphipathic helices, is thought to coordinate curvature acquisition with both fission and uncoating of clathrin-coated vesicles via the interaction of its carboxy-terminal $\mathrm{SH} 3$ domain with dynamin and the $\mathrm{PI}(4,5) \mathrm{P}_{2}$ phosphatase synaptojanin (Ringstad et al. 2001). Endophilin was proposed to start acting at early stages of clathrin-mediated budding, based on antibody-microinjection experiments in giant lamprey axons (Ringstad et al. 1999). However, more recent imaging studies (Perera et al. 2006; Ferguson et al. 2009; Taylor et al. 2011) and genetic studies in Drosophila, C. elegans, and mice, favor late actions (Schuske et al. 2003; Verstreken et al. 2003; Dickman et al. 2005; Milosevic et al. 2011), primarily in uncoating via endophilin's property to recruit synaptojanin. However, a study in C. elegans has suggested dynamin- and synaptojanin-independent action of endophilin (Bai et al. 2010). Because vesicles can be generated, albeit inefficiently, in the absence of endophilin (Schuske et al 2003; Verstreken et al. 2003; Milosevic et al. 2011), some functions of endophilin in curvature generation/sensing may also be fulfilled by other BAR domain-containing proteins, e.g., amphiphysin, SNX9/SNX18, and tuba (Itoh and De Camilli 2006). Lack of amphiphysin produces only mild defects in synaptic vesicle endocytosis, and its precise site of action remains to be defined (Di Paolo et al. 2002b; Pant et al. 2009). 
Based on studies of nonneuronal cells, $\mathrm{FCHo}$, which shares properties of adaptors (see above), was reported to function as the "nucleator" of clathrin-coated pits and as a first inducer of their curvature through its shallow F-BAR domain (Henne et al. 2010). This proposal is supported by its early presence at sites of clathrin-coated pit nucleation along with intersectin and Eps15. A role of an FCHo family member at synapses, however, has not been explored yet. The precise site of action and the role of other F-BAR proteins, such as members of the Toca/Fbp17/CIP4 family, syndapin, as well of nervous wreck in flies, remains to be established, despite their abundance in nerve terminals and of evidence that they participate in endocytosis (Kessels and Qualmann 2004; Dawson et al. 2006; Itoh and De Camilli 2006; Andersson et al. 2008; Rodal et al. 2008; Bu et al. 2010; Wu et al. 2010; Koch et al. 2011).

\section{PHOSPHOINOSITIDE METABOLISM}

Some proteins that directly or indirectly interact with core components of endocytic clathrincoated pits are phosphoinositide-metabolizing enzymes, thus (1) lending support to the physiological importance of the interaction of clathrin adaptors with $\mathrm{PI}(4,5) \mathrm{P}_{2}$ and (2) suggesting that $\mathrm{PI}(4,5) \mathrm{P}_{2}$ metabolism is tightly coupled to endocytic clathrin coat dynamics (Table 1). Synaptojanin 1 , a $\mathrm{PI}(4,5) \mathrm{P}_{2}$ phosphatase that can dephosphorylate both the 4 and 5 position of the inositol ring, interacts with endophilin and other BAR proteins (McPherson et al. 1996; Guo et al. 1999; Ringstad et al. 2001). It is therefore recruited ( primarily by endophilin) at the necks of clathrin-coated pits just before fission and one of its main functions is to couple the fission reaction of endocytosis to the shedding of the adaptors during uncoating (Cremona and De Camilli 2001; Milosevic et al. 2011).

PIP kinase type $1 \gamma$ (PIPK1 $\gamma$ ), the major $\mathrm{PI}(4,5) \mathrm{P}_{2}$ synthesizing enzyme at synapses (Wenk et al. 2001), interacts with talin 2, a protein concentrated at synaptic junctions (Di Paolo et al. 2002a; Ling et al. 2002), and with the clathrin adaptor AP-2 (Krauss et al. 2006; Thieman et al. 2009), thus providing a mecha- nism to ensure efficient synthesis of $\mathrm{PI}(4,5) \mathrm{P}_{2}$ at the nerve terminal plasma membrane and in proximity to endocytic clathrin-coated pits in particular (Di Paolo et al. 2004). These findings have suggested a model according to which a cycle of $\mathrm{PI}(4,5) \mathrm{P}_{2}$ synthesis and hydrolysis is nested within the synaptic vesicle cycle (Fig. $2)$, with $\mathrm{PI}(4,5) \mathrm{P}_{2}$ being restricted to the plasma membrane (Di Paolo and De Camilli 2006). Because synaptojanin 1 can dephosphorylate $\mathrm{PI}(4,5) \mathrm{P}_{2}$ to PI, PI 4-kinases are also thought to be involved in this cycle. A PI 4-kinase activity was reported on synaptic vesicles (Guo et al. 2003), but PI4P is also synthesized at the plasma membrane (Balla et al. 2008). The source of PI4P implicated in the vesicle cycle and the PI 4-kinase(s) involved remain a matter of debate (Di Paolo and De Camilli 2006).

Other phosphoinositide metabolizing enzymes, such as the inositol 5-phosphatases SHIP2 (Nakatsu et al. 2010) and OCRL (Erdmann et al. 2007; Mao et al. 2009) and the type II PI 3-kinases, also interact with clathrin coat components (Domin et al. 2000; Nakatsu et al. 2010). However, although such interactions further support the critical role of $\mathrm{PI}(4,5) \mathrm{P}_{2}$ in clathrin-coated pit dynamics, no direct evidence that they play an important role in synaptic vesicle recycling has been obtained so far. Drosophila studies showed a role of Tweek in synaptic vesicle recycling via a functional link to $\mathrm{PI}(4,5) \mathrm{P}_{2}$, but the mechanism of action of this protein is unknown (Verstreken et al. 2009).

\section{SCAFFOLDING}

The modular structure of some accessory proteins of the clathrin coat is specially designed to provide scaffolding functions for the assembly of other factors. In two large proteins, intersectin and tuba/DNMBP, this function is particularly evident (Table 1). Intersectin contains in sequence (i) amino-terminal EH domains that bind other endocytic factors such as epsin, stonin 2, FCHo and syndapin, (ii) a coiledcoil region involved in homodimerization or heterodimerization with Eps15 (a smaller scaffold protein containing $\mathrm{EH}$ domains and AP-2 binding sites), and (iii) $\mathrm{SH} 3$ domains that 


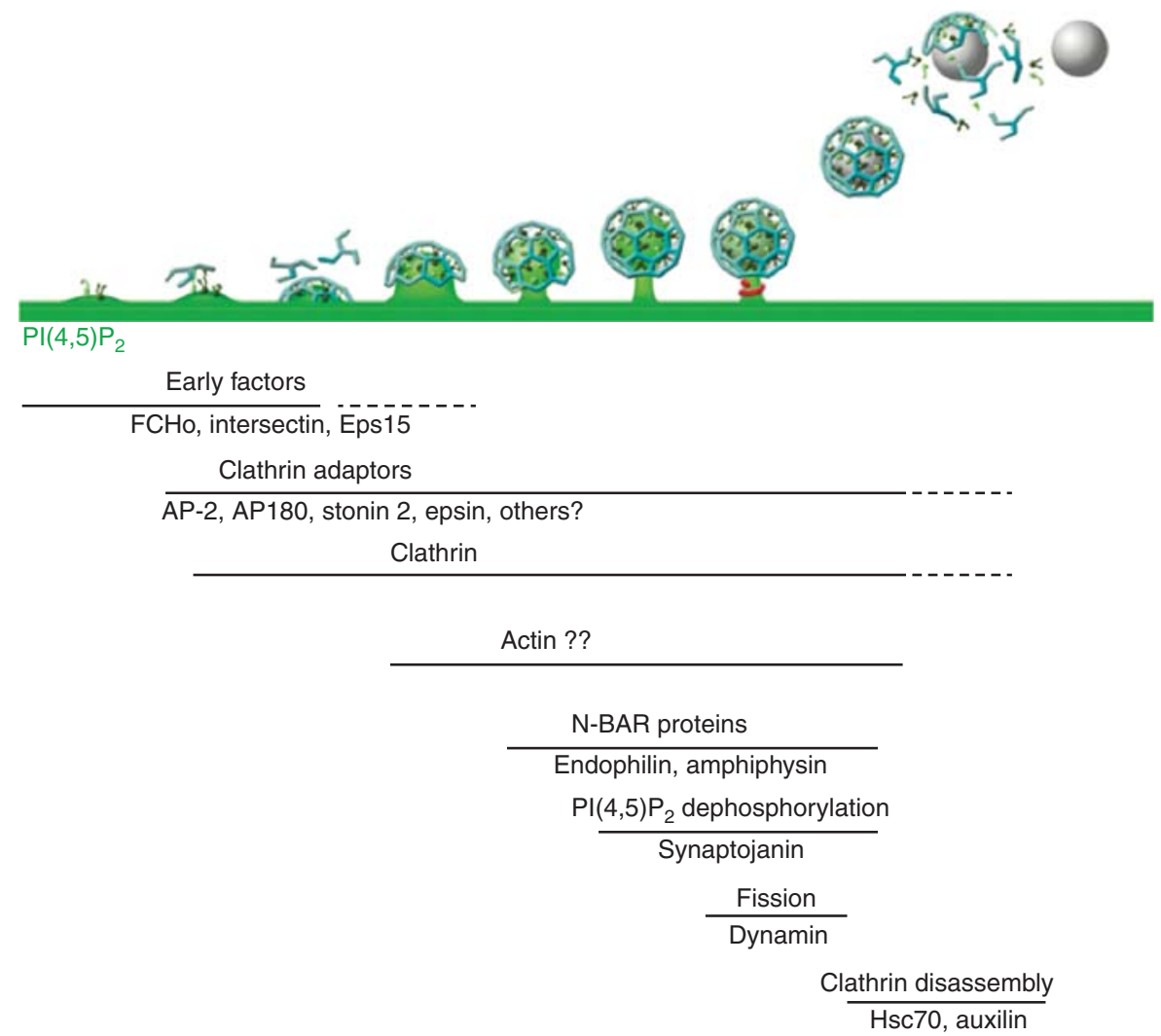

Figure 2. Sequential recruitment of endocytic proteins during clathrin-mediated synaptic vesicle endocytosis. Assembly and maturation of endocytic clathrin-coated pits involves the sequential action of a variety of protein factors. Putative sites of action of various factors are indicated (see text for discussion). $\mathrm{PI}(4,5) \mathrm{P}_{2}$ (green), which is generated at the synaptic plasma membrane primarily by PIP kinase type $1 \gamma$ (PIPK1 $\gamma$ ), plays a critical role both in exocytosis and in the recruitment of endocytic factors.

collectively bind dynamin, synaptojanin, $\mathrm{N}$ WASP, and several signaling proteins (Yamabhai et al. 1998; Okamoto et al. 1999; Marie et al. 2004; Kelly and Phillips 2005; Montesinos et al. 2005; Malacombe et al. 2006; Pechstein et al. 2010a). A long intersectin isoform selectively expressed in the nervous system of vertebrates contains an additional carboxy-terminal extension containing a DH-PH module that acts as a guanine nucleotide exchange factor (GEF) for Cdc42 (an actin regulatory protein) and a C2 domain (Hussain et al. 2001; Pechstein et al. 2010a). Tuba/DNMBP comprises a central DH-BAR module that also acts as a Cdc42 activator. This domain is flanked by amino-terminal SH3 domains that bind dynamin, and by car- boxy-terminal SH3 domains that bind $\mathrm{N}$ WASP and a variety of actin regulatory proteins (Hussain et al. 2001; Salazar et al. 2003; Kelly and Phillips 2005; Pechstein et al. 2010a). Because N-WASP and active Cdc42 act synergistically to stimulate Arp2/3-dependent actin nucleation, an important function of these scaffold proteins is to control actin dynamics at endocytic sites.

The importance of intersectin and of its binding partner Eps 15 in coordinating the function of multiple early endocytic factors in endocytosis (Henne et al. 2010), including synaptic vesicle endocytosis, is supported by genetic studies (Salcini et al. 2001; Koh et al. 2004, 2007; Marie et al. 2004; Rose et al. 2007) and by microinjection 
experiments in giant lamprey axons (Evergren et al. 2007). Tuba localizes to clathrin-coated pits (Ferguson et al. 2009), but its role in synaptic vesicle endocytosis remains to be shown.

\section{THE ACTIN CYTOSKELETON}

Several clathrin accessory factors are directly or indirectly linked to the regulation of the actin cytoskeleton (Table 1). The examples of intersectin and tuba were mentioned above. These proteins activate $\mathrm{Cdc} 42$ via their $\mathrm{DH}$ domains (Hussain et al. 2001; Salazar et al. 2003). Active Cdc42, in turn, acts in concert with their interactor N-WASP to stimulate Arp2/3-dependent actin nucleation (Miki et al. 1998). $\mathrm{PI}(4,5) \mathrm{P}_{2}$, also present at endocytic sites, further activates N-WASP (Miki et al. 1996). Several other BAR/F-BAR domain-containing proteins besides tuba, such as syndapin, nervous wreck, and Toca family members (Toca-1/FBP17/ CIP4), bind N-WASP via their SH3 domains (Toca family members also bind active Cdc42) (Itoh and De Camilli 2006; Takenawa and Suetsugu 2007). These findings converge with many studies of clathrin-mediated endocytosis in a variety of systems to suggest a strong link between clathrin-mediated endocytosis and actin.

However, the role of actin in clathrin-mediated endocytosis at synapses has been and continues to be a highly debated issue. Studies of synapses of the giant axon of the lamprey have shown that actin-perturbing agents have a powerful inhibitory action on clathrin-dependent synaptic vesicle recycling (Shupliakov et al. 2002; Bourne et al. 2006). In contrast, pharmacological disruption of actin did not seem to affect clathrin-mediated endocytosis at mammalian CNS synapses in vitro (Sankaranarayanan et al. 2003). Conflicting results on the role of actin in clathrin-mediated endocytosis have also been reported for non-neuronal cells (Merrifield et al. 2005; Ferguson et al. 2009; Saffarian et al. 2009). The emerging consensus is that actin dynamics may help counteract membrane tension, so that its importance varies depending on the tension of the membrane and the geometry of the membrane patch to be internalized (Boulant et al. 2011).
How could actin function in endocytosis? Important lessons have been learned from yeast, in which clathrin is implicated in the endocytosis that occurs at actin patches (Engqvist-Goldstein and Drubin 2003; Kaksonen et al. 2003). Although this process differs in many respects from clathrin-mediated endocytosis in metazoan-for example, yeast endocytic buds have a tubular rather than a spherical shape, the fission reaction does not require dynamin, and the dependence on actin is much stronger-several important features are conserved (Kaksonen et al. 2005; Ferguson et al. 2009). Thus, the many advantages offered by this organism for the functional characterization of proteins with genetic methods have greatly helped define a sequence of action of many endocytic factors and of actin in particular. As in mammalian cells, endocytosis in yeast starts with the assembly of clathrin coat proteins, and many of the subsequent stages are orchestrated by proteins whose homologs are also present at mammalian clathrin-coated pits (Kaksonen et al. 2005; Ferguson et al. 2009; Taylor et al. 2011). Importantly, yeast studies have shown that $\mathrm{N}$ WASP- and Arp2/3-dependent actin polymerization plays a major role in the invagination of the buds and in the events leading to fission (Kaksonen et al. 2005). Analysis of clathrin-mediated endocytosis in mammalian cells, either in living cells or in a cell-free system under conditions in which endocytosis is blocked, has supported this model because they have shown an actin dependence of the elongation/tubulation of the neck of the arrested clathrin-coated pits (Ferguson et al. 2009; Wu et al. 2010).

\section{MEMBRANE FISSION}

Although the clathrin coat and some of its interactors can drive progression of an endocytic bud to a deeply invaginated state, the physical separation of the clathrin-coated bud to generate a free vesicle requires the GTPase dynamin, a member of a family of membrane-remodeling GTPases (Table 1) (Praefcke and McMahon 2004; Ferguson and De Camilli 2012). Dynamin oligomerizes into spirals at bud necks and mediates fission in a process involving GTP 
hydrolysis (Hinshaw and Schmid 1995; Takei et al. 1995; Roux et al. 2006; Pucadyil and Schmid 2008). Of the three dynamins encoded by the human genome, dynamin 1 and dynamin 3 are expressed almost uniquely in the brain (Cao et al. 1998), where dynamin 1 is present by far at the highest concentration, whereas dynamin 2 is expressed at much lower concentration in all cells (Ferguson et al. 2007, 2009). A striking demonstration of the importance of dynamin in endocytosis is provided by the temperature-sensitive shibire mutation in Drosophila (Koenig and Ikeda 1989). Within less than a minute following a shift to the restrictive temperature, these mutant flies become paralyzed owing to a depletion of synaptic vesicles. Although their synaptic vesicles continue to fuse with the plasma membrane, their endocytosis is arrested at the stage of "collared" buds (Koenig and Ikeda 1989). A dramatic arrest of clathrinmediated endocytosis was also observed in a variety of model synapses after perturbation of dynamin function (by dominant-negative interference or pharmacological inhibition) (Shupliakov et al. 1997; Yamashita et al. 2005; Newton et al. 2006), and more recently, at mouse synapses that lack dynamin 1 (Ferguson et al. 2007), or, in a more severe form, at synapses that lack both dynamin 1 and 3 (Raimondi et al. 2011). At such synapses, the arrest of clathrin-coated pit fission leads to a massive accumulation of clathrin-coated pits on deep plasma membrane invaginations that may fill the entire nerve terminal and replace the synaptic vesicle cluster (Ferguson et al. 2007; Hayashi et al. 2008; Raimondi et al. 2011). Surprisingly, neither dynamin 1 nor even dynamin 1 and 3 together, are essential for the occurrence of clathrin-mediated endocytosis at low level of activity. The presence of high levels of dynamin (primarily dynamin 1) at synapses is needed to allow the rate of endocytosis to scale with an increase of the secretory response (Lou et al. 2008). In the absence of dynamin 1 and 3, probability of release is reduced, most likely to prevent synaptic transmission failure owing to vesicle depletion (Lou et al. 2012).

The precise mechanism through which dynamin mediates fission remains unclear, but re- cent structural studies have provided significant insight. These studies have confirmed that dynamin is a member of a family of GTPases whose catalytic activity is dependent on the GTP-dependent dimerization of the GTPase module (Gasper et al. 2009; Chappie et al. 2010; Ferguson and De Camilli 2012). Importantly, they have shown that such dimerization can only occur between adjacent rungs within the dynamin spiral and that GTP hydrolysis results in a conformational change of neighboring domains to produce a constriction of the dynamin spiral and thus of the underlying tubular bud neck (Chappie et al. 2011; Faelber et al. 2011; Ford et al. 2011). It remains unclear whether fission is the direct result of this constriction or of the disassembly that follows constriction and that exposes an unstable narrow tubular intermediate (Roux et al. 2006; Mears et al. 2007; Bashkirov et al. 2008; Pucadyil and Schmid 2008; Low and Lowe 2010; Chappie et al. 2011; Faelber et al. 2011; Ford et al. 2011).

Dynamin recruitment occurs as pits mature to their deeply invaginated state (Merrifield et al. 2002; Perera et al. 2006; Taylor et al. 2011). The $\mathrm{PH}$ domain of dynamin, which binds acidic phospholipids and $\mathrm{PI}(4,5) \mathrm{P}_{2}$, and the prolinerich carboxy-terminal region, which functions as a protein-protein interaction domain, are important for dynamin's function and recruitment (Okamoto et al. 1997; Shupliakov et al. 1997; Lee et al. 1999; Vallis et al. 1999; Szaszak et al. 2002). Many of the proteins that bind this region (generally through $\mathrm{SH} 3$ domains) are BAR domain-containing proteins and thus proteins that may help coordinate formation of the vesicle neck with the recruitment of dynamin (Itoh and De Camilli 2006). Importantly, BAR proteins that bind dynamin often also bind the $\mathrm{PI}(4,5) \mathrm{P}_{2}$ phosphatase synaptojanin and or $\mathrm{N}$ WASP, thus suggesting a functional partnership between these proteins (Itoh and De Camilli 2006; Takenawa and Suetsugu 2007). Indeed, the recruitment of synaptojanin to sites of fission couples separation of the coated bud from the plasma membrane with its uncoating. It has also been proposed that the $\mathrm{PI}(4,5) \mathrm{P}_{2}$ phosphatase activity of synaptojanin may have a direct action in fission by creating a lipid-phase 
boundary, and thus an interfacial force, between a $\mathrm{PI}(4,5) \mathrm{P}_{2}$-depleted bud and the $\mathrm{PI}(4,5) \mathrm{P}_{2}$-rich plasma membrane (Liu et al. 2009), or by promoting the dissociation of dynamin after constriction of the dynamin collar (Chang-Ileto et al. 2010). However, genetic studies in mice support a primary uncoating function of synaptojanin, although they do not rule out other roles. (Cremona et al. 1999; Hayashi et al. 2008; Milosevic et al. 2011). Concerning N-WASP, its activation in proximity of dynamin (Kessels and Qualmann 2002; Koch et al. 2011) may reflect a role of actin in neck formation/elongation (see above yeast studies) or in fission, by providing tension at bud necks, or in propelling newly formed vesicles away from endocytic sites.

\section{UNCOATING}

After fission, newly generated clathrin-coated vesicles rapidly shed their coat proteins and are recaptured in the synaptic vesicle cluster for reuse. Clathrin shedding is ATP-dependent and requires $\mathrm{Hsc70}$ ATPase and its cofactor auxilin (Guan et al. 2010; Xing et al. 2010; Yim et al. 2010), whereas shedding of the adaptors is dependent on $\mathrm{PI}(4,5) \mathrm{P}_{2}$ hydrolysis by the $\mathrm{PI}(4,5) \mathrm{P}_{2}$ phosphatase synaptojanin (Table 1 ). Genetic disruption of synaptojanin 1, or of endophilin (the protein that plays a critical role in recruiting synaptojanin to endocytic sites), produces a striking accumulation of clathrincoated vesicles in nerve terminals and delayed recycling kinetics in mice, worms, and flies (Cremona et al. 1999; Schuske et al. 2003; Verstreken et al. 2003; Dickman et al. 2005; Hayashi et al. 2008; Milosevic et al. 2011). It is the combined action of Hsc70 and synaptojanin that makes the uncoating reaction "catastrophic" and irreversible. A critical question is how these two reactions are coordinated. Although auxilin binds clathrin and AP-2, its recruitment to budding coated vesicles also requires its tensin homology domain (a tandem arrangement of a PTEN-like phosphatase domain and a C2 domain). Because the tensin homology domain binds membrane monophosphoinositides (Guan et al. 2010), it has been proposed that the catalytic action of synaptojanin 1 may mediate such coordination. Conversion of $\mathrm{PI}(4,5) \mathrm{P}_{2}$ to PI4P by synaptojanin would not only remove membrane-binding sites for the clathrin adaptors but also generate binding sites for auxilin (Guan et al. 2010).

\section{SPATIAL SEGREGATION OF EXO- AND ENDOCYTIC SITES}

Clathrin-coated pits are typically observed at the outer margins of the active zones of secretion (Heuser and Reese 1973; Heuser 1989; Pieribone et al. 1995; Gad et al. 1998; Bloom et al. 2003). This spatial segregation is likely explained by the presence of a highly specialized membrane anchored matrix at the active zone, which is involved in capturing and docking of synaptic vesicles in preparation for exocytosis (Jin and Garner 2008). Although active mechanisms for the rapid export of components of the newly fused membrane away from sites of exocytosis cannot be excluded, the nonexpandable nature of the active zone, which is in precise register with, and anchored to, the postsynaptic membrane, may be sufficient to account for a rapid passive translocation of newly fused membrane material. Only after massive nerve terminal perturbations is the active zone disrupted (Shupliakov et al. 1997).

The area that surrounds the active zone and that is specialized for endocytosis forms an anatomically and biochemically distinct domain called the endocytic or periactive zone (Wan et al. 2000). This zone, which is particularly obvious at some specialized giant synapses such as those of lamprey reticulospinal axons, is typically marked by the presence of actin (Fig. 3), thus providing important evidence for the strong link between actin and endocytosis (Pieribone et al. 1995; Gad et al. 1998; Bloom et al. 2003). Studies in Drosophila have shown that several mutations in endocytic genes (e.g., synaptojanin, intersectin, nervous wreck, and endophilin) also produce defects in bouton size and organization at neuromuscular junctions (Rikhy et al. 2002; Coyle et al. 2004; Koh et al. 2004, 2007; Marie et al. 2004; Dickman et al. 2006). This finding may be explained by the importance of these genes both for endocytosis 
and for actin function or by indirect effects of an endocytic impairment on signaling pathways that control synaptic size.

\section{COUPLING BETWEEN EXOCYTOSIS AND ENDOCYTOSIS}

In nonneuronal cells, clathrin-mediated endocytosis is predominantly a constitutive process. In contrast, at synapses, clathrin-dependent endocytosis is primarily a compensatory reaction aimed at recapturing excess membrane delivered to the cell surface by exocytosis. Accordingly, clathrin-coated profiles are rarely observed in resting nerve terminals, and their number greatly increases after stimulation (Heuser and Reese 1973; Gad et al. 1998). This implies the occurrence in nerve endings of a large pool of "nonengaged" clathrin coat proteins and of mechanisms to trigger their engagement during and after a stimulus.

A key trigger for the endocytic burst that follows a stimulus is the exocytic delivery of synaptic vesicle membranes to the plasma membrane, where they act as nucleating sites for coated pits. This function is mediated by binding sites for endocytic clathrin adaptors that are present in the cytoplasmic domains of several synaptic vesicle proteins but that need to be presented in the context of a $\mathrm{PI}(4,5) \mathrm{P}_{2}$-rich membrane (the plasma membrane) to trigger efficient recruitment of the adaptors. Because of the lack of $\mathrm{PI}(4,5) \mathrm{P}_{2}$ on synaptic vesicles, exocytosis represents the switch that makes these sites competent for adaptor recruitment (Fig. 2) (Di Paolo and De Camilli 2006). Interestingly, the presence of $\mathrm{PI}(4,5) \mathrm{P}_{2}$ in the plasma membrane also plays an important role in defining this membrane as the target for synaptic vesicle exocytosis and $\mathrm{Ca}^{2+}$-dependent fusion (Osborne et al. 2001; Bai et al. 2004; Gong et al. 2005; Milosevic et al. 2005). PI $(4,5) \mathrm{P}_{2}$, therefore, plays a fundamental role in exo-endocytosis coupling.

An important open question that has implications for the exo-endocytic coupling is the

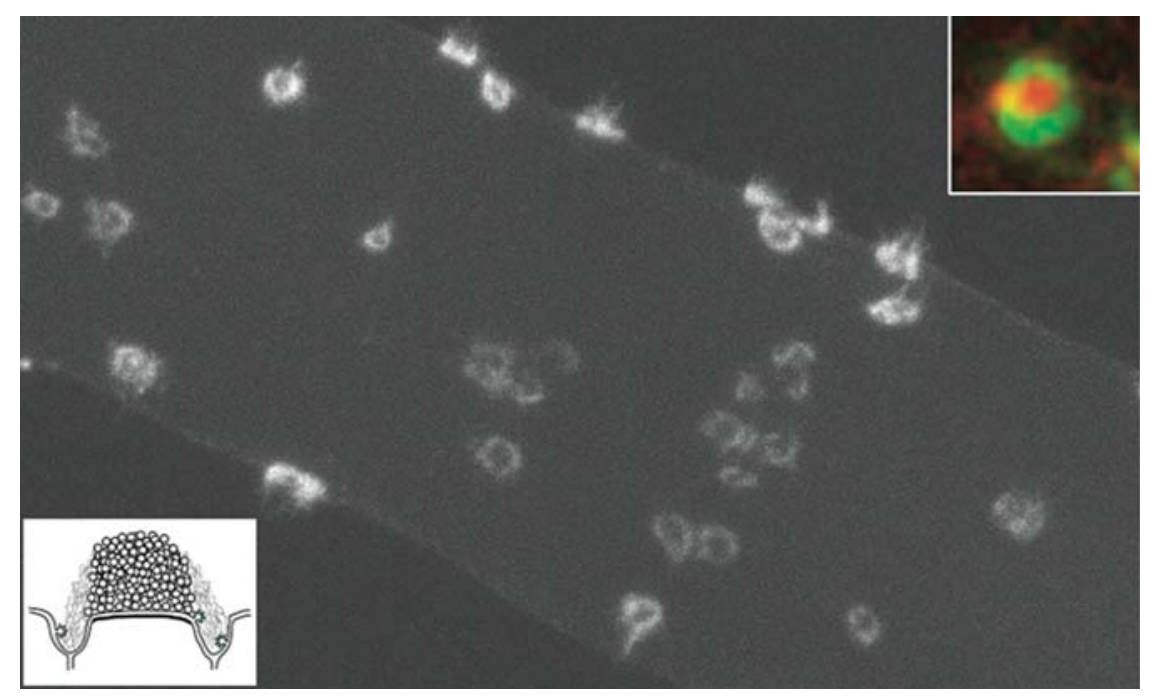

Figure 3. Presence of actin at periactive zones of synapses of the giant reticulospinal axon of the lamprey. Fluorescence image of a giant axon microinjected with Alexa Fluor 488-phalloidin. Fluorescent rings represent actin at periactive zones surrounding the vesicle cluster. The top inset is from an axon preincubated with an FM dye (red) to produce an endocytic labeling of synaptic vesicles, then fixed and labeled with phalloidin (green) to reveal actin. Note the actin ring nesting the vesicle cluster. The bottom inset is a schematic diagram of the synapses of the giant axon illustrating the vesicle cluster and the periactive zone ( $\mathrm{J}$ Morgan, $\mathrm{V}$ Pieribone, and $\mathrm{P}$ De Camilli, unpubl.). 
fate of vesicle proteins after the collapse of the vesicle into the plasma membrane. Removal of newly fused membrane material from sites of fusion seems to be required for new vesicles to dock (Hosoi et al. 2009). Whether vesicle proteins retain some association with each other after fusion, or disperse throughout the plasma membrane remains a debated issue. If they disperse and intermix with a small pool of synaptic vesicle proteins already present at the cell surface, the molecules taken up by compensatory endocytosis may not necessarily be the newly delivered ones (Tabares et al. 2007). Supporting this idea, the existence of a rapidly retrievable pool of synaptic vesicle proteins ( possibly a preassembled endocytic patch or bud) whose endocytosis is triggered by exocytosis, was recently suggested (Fernandez-Alfonso et al. 2006; Wienisch and Klingauf 2006; Hua et al. 2011). Such a preassembly may explain the stochastic distribution of endocytic events after a single action potential (time constant $\sim 14 \mathrm{sec}$ ) with such events occurring as early as 1-2 sec after exocytosis (Balaji and Ryan 2007), i.e., an extremely short delay that seems difficult to reconcile with the formation of a new clathrin-coated pit (Kirchhausen 2009). The coupling between exocytosis and the internalization of preformed buds may be triggered by the decrease in surface tension resulting from expansion of the plasma membrane produced by exocytosis (Dai et al. 1997). Clearly, as shown by the analysis of capacitance in response to a secretory stimulus, the surface of an axon ending is set at a very precise value, and compensatory endocytosis rapidly resets an increase in surface area to the original value (Fig. 1D).

Another debated issue is whether and how the increase in cytosolic $\mathrm{Ca}^{2+}$ that has a critical role in exocytosis also plays some role(s) in the regulation of the subsequent endocytic process. Although there is evidence that cytosolic $\mathrm{Ca}^{2+}$ is needed for endocytosis, elevations of cytosolic $\mathrm{Ca}^{2+}$ above its physiological levels are not essential for this process (Ceccarelli and Hurlbut 1980; Wu and Betz 1996; Gad et al. 1998; Balaji et al. 2008). However, a transient elevation in cytosolic $\mathrm{Ca}^{2+}$ triggers various forms of clathrin-independent endocytosis in a variety of cell types (Artalejo et al. 1995; Neves et al. 2001; Wu et al. 2009; Lariccia et al. 2010), and a stimulus-dependent cytosolic $\mathrm{Ca}^{2+}$ increase may also play a role in bulk endocytosis at synapses. Furthermore, a sustained increase in cytosolic $\mathrm{Ca}^{2+}$ accelerates endocytosis (Sankaranarayanan and Ryan 2000, 2001; Wu et al. 2005; Balaji et al. 2008). A synaptic vesicle protein, flower, was proposed to oligomerize and to form a $\mathrm{Ca}^{2+}$ channel on exocytosis, thus contributing to the coupling between exo- and endocytosis (Yao et al. 2009).

The regulatory effect of $\mathrm{Ca}^{2+}$ on endocytosis may be mediated by $\mathrm{Ca}^{2+}$ effectors that participate in the endocytic reaction (for example, synaptotagmin, which is thought to function as a $\mathrm{Ca}^{2+}$ sensor, acts both in exocytosis and in endocytosis [Yao et al. 2011]), but also by phosphorylation-dephosphorylation reactions. Importantly, several endocytic proteins are constitutively phosphorylated in resting nerve terminals but undergo rapid dephosphorylation by calcineurin $\left(\mathrm{a} \mathrm{Ca}^{2+}\right.$-calmodulin-dependent phosphatase) on stimulation. These proteins, sometimes referred to as dephosphins, include proteins with different functions in endocytosis including dynamin, synaptojanin, PIPKI $\gamma$, AP180, epsin, Eps15, and several others (Liu et al. 1994; McPherson et al. 1994; Chen et al. 1999; Cousin and Robinson 2001; Lee et al. 2004, 2005; Nakano-Kobayashi et al. 2007). Typically, their dephosphorylation enhances their interactions with other endocytic factors and promotes their recruitment to endocytic sites (Liu et al. 1994; Slepnev et al. 1998; Anggono et al. 2006). Conversely, their constitutive phosphorylation, mediated at least in part by Cdk5, may serve to keep them inactive yet concentrated in nerve terminals by interactions that are mutually exclusive with those responsible for endocytosis (Tan et al. 2003; Tomizawa et al. 2003; Lee et al. 2005). Thus, phosphorylated endocytic proteins may represent a reservoir from which proteins can be recruited on stimulation. The $\mathrm{Ca}^{2+}$ dependent dephosphorylation of PIPK1 $\gamma$ and synaptojanin 1 is of particular interest, because such dephosphorylation is coupled to their recruitment and activation (Lee et al. 2004, 2005; 
Nakano-Kobayashi et al. 2007). This may represent a mechanism to couple the traffic of synaptic proteins through the plasma membrane with a metabolic flux of $\mathrm{PI}(4,5) \mathrm{P}_{2}$.

Other changes that are dependent on synaptic vesicle exocytosis, but not necessarily on $\mathrm{Ca}^{2+}$-dependent dephosphorylation, may help link exo- to endocytosis. Some endocytic proteins are bound to the synaptic vesicle cluster and relocate to the periactive zone after stimulation (Evergren et al. 2007). In the case of endophilin, such reversible relocation was proposed to be linked to the exocytosis-dependent shedding of Rab3, a synaptic vesicle-associated protein (Bai et al. 2010).

\section{KISS AND RUN}

Clathrin-mediated budding provides a mechanism to generate a vesicle enriched in a specific cargo. The need for a molecular sorting mechanism to select cargo could be bypassed if vesicles did not fully collapse into the plasma membrane after fusion, thus retaining their identity. The potential existence of this endocytic mechanism, subsequently called kiss and run (Fesce et al. 1994), was raised already at the time when synaptic vesicle recycling was first described in studies of the frog neuromuscular junction (Ceccarelli et al. 1973; Heuser and Reese 1973; He and Wu 2007). Although the importance of clathrin-mediated endocytosis was subsequently corroborated by biochemical, biophysical, and genetic studies, evidence for kiss and run of synaptic vesicles remains primarily indirect, based on observations that appear incompatible with clathrin-mediated endocytosis or bulk endocytosis. Such evidence includes incomplete discharge of FM dyes (Aravanis et al. 2003), quenching of the incompletely released FM dye by the presence of the membrane-impermeant extracellular tracer bromophenol blue (BPB) (Harata et al. 2006), capacitance measurements of giant synapses (He et al. 2006), and recycling of quantum dots trapped in synaptic vesicles (Zhang et al. 2009). It is important to note that even studies that support kiss and run acknowledge the occurrence of parallel endocytic pathways.
What mechanism(s) could account for kiss and run of synaptic vesicles? A highly curved bilayer, such as that of synaptic vesicles, would be expected to immediately flatten in the plasma membrane on fusion, unless there were mechanisms to favor bilayer curvature retention. Such mechanisms must have come into play to impose curvature when the vesicle was generated. Thus, the fate of the vesicle after fusion will depend on whether determinants of membrane curvature are retained on the membrane after vesicle budding. Current evidence suggests that curvature is imposed by core and accessory components of the clathrin coat, although other mechanisms, such as lipid bilayer asymmetries or roles of wedge-shaped membrane proteins, cannot be excluded. Thus, uncoating is predicted to leave behind a "stressed" membrane with a propensity to flatten on exocytosis. Mechanisms that could prevent flattening of a "stressed" membrane could include (1) an only incomplete fusion of the two bilayers, with a flickering of the fusion pore that allows escape of the small neurotransmitter molecules, but does not proceed to full fusion; (2) the presence of a collar at the site of fusion that prevents neck opening; and (3) a rigid structure of the active zone plasma membrane that cannot accommodate a flattening of the "extra" membrane added by exocytosis. Whether any of these mechanisms comes into play at synapses is not known.

Compelling evidence for the occurrence of kiss-and-run fusion (also called cavicapture, to indicate the recovery of a cavity) was obtained for peptide- and amine-containing secretory granules of neuroendocrine cells and for large secretory vesicles of other cells (Albillos et al. 1997; Holroyd et al. 2002; Taraska et al. 2003). It should be noted, however, that the time courses of fusion-fission events for these types of vesicles (seconds) (Albillos et al. 1997) are much longer than those involved in the fusion of synaptic vesicles (milliseconds). The different physicochemical properties of these granules, such as lower curvature of the membrane and presence of a protein core that undergoes slow solubilization, are factors that may favor the flickering of the fusion pore. 


\section{BULK ENDOCYTOSIS}

This form of synaptic vesicle endocytosis operates most prominently under strong stimulatory conditions, when a large number of synaptic vesicles fuse with the plasma membrane within a short time interval. Excess plasma membrane is rapidly recaptured via the formation of plasma membrane infoldings, which then undergo fission to generate intracellular vacuoles and cisternae (endosome-like intermediates) (Heuser and Reese 1973; Miller and Heuser 1984; Holt et al. 2003; Paillart et al. 2003; Wu and Wu 2007; Clayton et al. 2008; Hayashi et al. 2008). This process is a nonselective mechanism of membrane uptake. However, the resulting endosome-like intermediates may be enriched with intrinsic synaptic vesicle membrane proteins given the abundance of these proteins in the plasma membrane in response to a burst of synaptic vesicle exocytosis (Heuser and Reese 1973). The vacuoles subsequently disappear as new vesicles appear, indicating a precursor-product relationship between these organelles and new synaptic vesicles (Heuser and Reese 1973; Teng et al. 2007; Clayton et al. 2008).

The molecular mechanisms underlying bulk endocytosis remain largely unknown. The increase in surface to volume ratio resulting from massive exocytosis may help to buckle the plasma membrane, leading to the generation of deep infoldings (Torri-Tarelli et al. 1987). However, their fission from the plasma membrane implies an active mechanism. Such a mechanism appears to be dynamin independent because it occurs robustly even in the absence of dynamin 1 (by far the most abundant neuron-specific dynamin), when clathrin-mediated endocytosis is severely impaired (Ferguson et al. 2007; Hayashi et al. 2008; and our unpublished observations). The actin cytoskeleton and proteins that couple membrane deformation to actin dynamics such as BAR superfamily proteins (Itoh and De Camilli 2006) may be involved in this form of endocytosis. Supporting this possibility, the F-BAR protein syndapin was implicated in this process (Andersson et al. 2008; Clayton et al. 2009). Additionally, a form of bulk endocytosis was recently reconstituted in vitro using isolated plasma membrane lawns and brain cytosol, and this process was shown to involve both actin and F-BAR proteins (Wu et al. 2010).

A key question that remains unsolved is how the large vacuoles (endocytic intermediates) that form by bulk endocytosis eventually convert to new synaptic vesicles (see Fig. 1A). Several potential scenarios can be considered. A first possibility is the back fusion of these vacuoles with the plasma membrane for piecemeal recapture by clathrin-mediated endocytosis. In this scenario, one can envisage only one pathway to the generation of synaptic vesicles, clathrin-dependent endocytic budding. However, robust conversion of the vacuoles was observed even at synapses that lack dynamin 1 , in which clathrin-mediated endocytosis is severely impaired, thus questioning this possibility (Ferguson et al. 2007).

A second possibility is that new vesicles reform by a coat-mediated mechanism from the endocytic intermediates. Based on studies of broken cell preparations it had been proposed that such a reaction might occur via the same clathrin coat that mediates budding from the plasma membrane (Takei et al. 1996). On the other hand, more recent studies have shown an obligatory role of $\mathrm{PI}(4,5) \mathrm{P}_{2}$ in the assembly of such coats, and our studies suggest that endocytosis is coupled to $\mathrm{PI}(4,5) \mathrm{P}_{2}$ dephosphorylation, thus implicating absence of $\mathrm{PI}(4,5) \mathrm{P}_{2}$ from endocytic membranes in living cells (Cremona et al. 1999; Di Paolo and De Camilli 2006). Accordingly, EM tomographic studies have shown that the overwhelming majority of clathrincoated pits present in intact nerve terminals are connected to the plasma membrane, even when they appear to be emerging from endosomes in single EM sections (Fig. 4) (Ferguson et al. 2007; Hayashi et al. 2008; Raimondi et al. 2011). Thus, if coats are involved, such coats should be different from endocytic clathrin coats. AP-3 and AP-1, heterotetrameric complexes similar to AP-2 that may function independently of clathrin, are potential candidates (Faundez et al. 1998; Nakatsu et al. 2004; Kim and Ryan 2009; Newell-Litwa et al. 2009; Glyvuk et al. 2010). However, although both AP-3 and AP-1 were implicated in synaptic vesicle recycling 

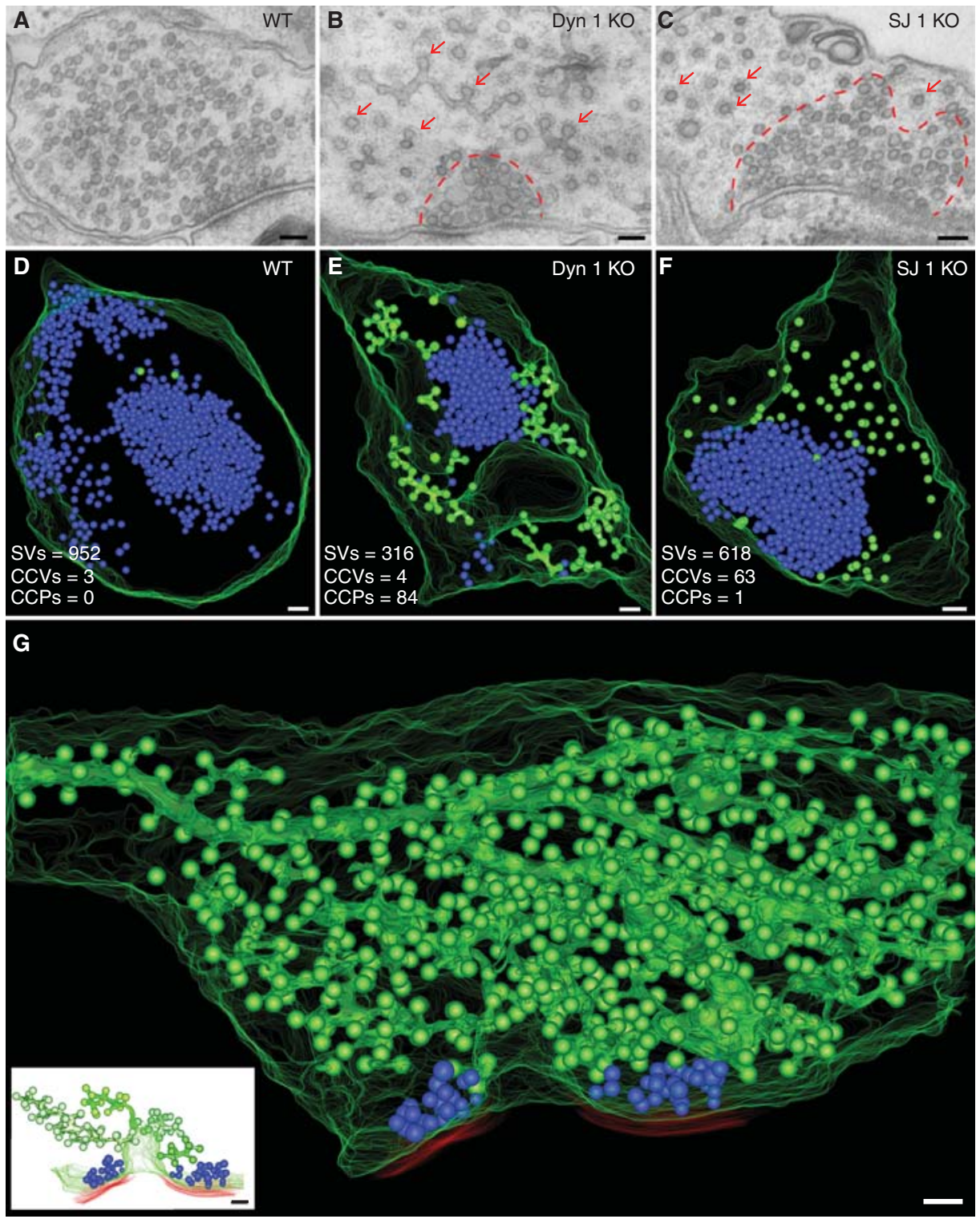

Figure 4. Ultrastructure and 3D models of wild-type (WT), dynamin 1 knockout (KO), and synaptojanin $1 \mathrm{KO}$ synapses demonstrating the accumulation of clathrin-coated intermediates in the KO synapses. $(A-C)$ Conventional electron micrographs of synapses from mouse primary cortical cultures of the indicated genotypes. Note the abundance of clathrin-coated profiles (arrows) in dynamin 1 and synaptojanin $1 \mathrm{KO}$ nerve terminals and the less dense packing of these structures relative to the packing of synaptic vesicles (SVs) (enclosed by dashed red lines). ( $D-F$ ) 3D models from the EM tomograms of 250-nm-thick sections of WT and mutant nerve terminals showing that the bulk of coated profiles (green) are buds that are located that at the tip of branched tubules in dynamin $1 \mathrm{KO}$ synapses and free vesicles in synaptojanin $1 \mathrm{KO}$ synapses. Synaptic vesicles are shown in blue. $(G)$ 3D model from the EM tomogram of an 800-nm-thick volume of a dynamin $1 \mathrm{KO}$ nerve terminal. Synaptic vesicles are blue spheres, the plasma membrane is outlined by a series of green curves, and red lines indicate postsynaptic membranes. The overwhelming majority of coated structures (green) are buds originating from tubular plasma membrane invaginations (four such invaginations are shown separately in the inset). (Scale bars, $100 \mathrm{~nm}$.) (Panel $G$ from Hayashi et al. 2008; reprinted, with permission, from the author. Bottom inset from Ferguson et al. 2007; reprinted, with permission, from Science (C) 2007.) 
(Voglmaier et al. 2006; Glyvuk et al. 2010), they do not appear to be major and general components of synapses.

A third possibility is that synaptic vesicles may reform from endocytic intermediates by a novel mechanism, either lipid-mediated or protein-mediated, but independent of classical coats (Kirchhausen 2000b; Graham 2004). For example, in vitro studies have shown that some proteins of the BAR superfamily that tubulate liposomes can also fragment them into small vesicles (Gallop et al. 2006; Wang et al. 2009). Although such a mechanism is unlikely to achieve the sorting of membrane cargo, efficient sorting may be dispensable, given the high concentration of synaptic vesicle proteins in these endosome-like intermediates. A problem with a direct, clathrin-independent, reformation of synaptic vesicles from endosomal structures is that such reaction would imply that a "well-defined" organelle, such as a synaptic vesicle, can be generated via two distinct pathways, clathrin-mediated endocytosis and an additional mechanism. Such a hypothesis seems unattractive. It should be noted, however, that synaptic vesicles reformed after a strong stimulus are often more heterogeneous in size than synaptic vesicles present in resting or mildly stimulated nerve terminals (Ferguson et al. 2007; Clayton et al. 2008; our unpublished observations). Thus, following a strong stimulus, the fidelity of synaptic vesicle reformation may be partially lost and a new cycle of exocytosis and clathrin-dependent endocytosis may be needed to reconstitute a vesicle with a well-defined composition and size. The possible occurrence of clathrin-independent mechanisms to support neurotransmission has been raised by recent studies in worms ( $\mathrm{Gu}$ et al. 2008; Sato et al. 2009). More work is clearly needed to investigate the provocative conclusions of these interesting studies.

\section{NERVE TERMINAL ENDOSOMES}

The role of "canonical" early endosomes in nerve terminals (i.e., organelles downstream from clathrin-coated vesicles and of other vesicles that form directly from the plasma membrane
[Helenius et al. 1983]) and the relation of vacuoles generated by bulk endocytosis to such endosomes remain a poorly explored topic. Canonical early endosomes, as defined by the presence of the endosomal markers Rab5 and PI3P ( Miaczynska et al. 2004), are expected to be present in axon endings, irrespective of synaptic vesicle traffic, given their ubiquitous importance in the sorting of endocytic traffic of plasma membrane components (including receptors, ion channels, transporters, etc.) (Miaczynska et al. 2004; Sann et al. 2009). Indeed both Rab5- and PI3P-positive organelles are present in nerve terminals (Wucherpfennig et al. 2003; Grill et al. 2007; Brown et al. 2009; Hoopmann et al. 2010). Furthermore, the SNARE Vtila, which is thought to participate in the fusion of synaptic vesicle membrane with endosomes, is present on synaptic vesicles (Antonin et al. 2000; Ramirez et al. 2012). However, Rab5-and PI3P-positive endosomes are quite few and small, and so far there is no evidence that the large vacuoles generated by bulk endocytosis are positive for these markers. Perturbation of Rab5 with a dominant-negative approach was shown to affect synaptic vesicle recycling only mildly (de Hoop et al. 1994; Wucherpfennig et al. 2003). On the other hand, Rab5 was also detected on synaptic vesicles, thus clouding the interpretation of these results (Fischer von Mollard et al. 1994; Pavlos et al. 2010). It is important to note that the concept of the endosome has been extensively revised in recent years. Endosomes are now considered a highly heterogeneous population of organelles, with a further local heterogeneity within a given organelle being defined by the presence of multiple Rabs, other small G proteins (Arls and Arfs), a wide variety of other peripheral factors, and different phosphoinositides [PI3P, $\mathrm{PI}(3,4) \mathrm{P}_{2}$ and $\left.\mathrm{PI}(3,5) \mathrm{P}_{2}\right]$ (Miaczynska et al. 2004; Zoncu et al. 2009; Scita and Di Fiore 2010). Stable endosomal populations coexist with endocytic compartments that expand and shrink dependent on the functional state of the cell (Miaczynska et al. 2004; Zoncu et al. 2009; Scita and Di Fiore 2010). A precise functional characterization of nerve terminal endosomes and other endocytic intermediates is an important priority for future studies. 


\section{CONCLUDING REMARKS}

The uniform size and biochemical composition of synaptic vesicles, which are now the best characterized cellular organelles (Takamori et al. 2006), is a key basis for the quantal property of neurotransmitter release. These organelles are continuously regenerated by endocytic membrane recycling. Although our understanding of this process has greatly advanced in recent years, much remains to be learned. Substantial mechanistic insight has been obtained for clathrin-mediated endocytosis, but little is known about parallel pathways that mediate the endocytic recapture of synaptic vesicles after an exocytic burst, bulk endocytosis in particular. The properties and dynamics of endosomal intermediates, most importantly the mechanisms through which they give rise to new synaptic vesicles, remain poorly understood. The small size of nerve terminals has made difficult the application to nerve terminals of fluorescence live imaging methods that have allowed monitoring the dynamics and fate of specific proteins and individual vesicles in other systems. However, advances in the field of superresolution microscopy and electron tomography methods offer new opportunities in this area. Genetic studies in model organisms and studies of genetic diseases of the human nervous system will continue to yield critical information about proteins involved in synaptic vesicle recycling. It can be anticipated that new progress in this area will not only advance the field of synaptic transmission but also have broad implications in cell biology and medicine.

\section{REFERENCES}

Albillos A, Dernick G, Horstmann H, Almers W, Alvarez de Toledo G, Lindau M. 1997. The exocytotic event in chromaffin cells revealed by patch amperometry. Nature 389: 509-512.

Andersson F, Jakobsson J, Low P, Shupliakov O, Brodin L. 2008. Perturbation of syndapin/PACSIN impairs synaptic vesicle recycling evoked by intense stimulation. J Neurosci 28: 3925-3933

Anggono V, Smillie KJ, Graham ME, Valova VA, Cousin MA, Robinson PJ. 2006. Syndapin I is the phosphorylationregulated dynamin I partner in synaptic vesicle endocytosis. Nat Neurosci 9: 752-760.
Antonin W, Riedel D, von Mollard GF. 2000. The SNARE Vtila- $\beta$ is localized to small synaptic vesicles and participates in a novel SNARE complex. J Neurosci 20: $5724-$ 5732.

Antonny B. 2006. Membrane deformation by protein coats. Curr Opin Cell Biol 18: 386-394.

Antonny B. 2011. Mechanisms of membrane curvature sensing. Annu Rev Biochem 80: 101-123.

Aravanis AM, Pyle JL, Tsien RW. 2003. Single synaptic vesicles fusing transiently and successively without loss of identity. Nature 423: 643-647.

Artalejo CR, Henley JR, McNiven MA, Palfrey HC. 1995. Rapid endocytosis coupled to exocytosis in adrenal chromaffin cells involves $\mathrm{Ca}^{2+}$, GTP, and dynamin but not clathrin. Proc Natl Acad Sci 92: 8328-8332.

Bai J, Tucker WC, Chapman ER. 2004. PIP2 increases the speed of response of synaptotagmin and steers its membrane-penetration activity toward the plasma membrane. Nat Struct Mol Biol 11: 36-44.

Bai J, Hu Z, Dittman JS, Pym EC, Kaplan JM. 2010. Endophilin functions as a membrane-bending molecule and is delivered to endocytic zones by exocytosis. Cell 143: 430441.

Balaji J, Ryan TA. 2007. Single-vesicle imaging reveals that synaptic vesicle exocytosis and endocytosis are coupled by a single stochastic mode. Proc Natl Acad Sci 104: 20576-20581.

Balaji J, Armbruster M, Ryan TA. 2008. Calcium control of endocytic capacity at a CNS synapse. J Neurosci 28: 67426749 .

Balla A, Kim YJ, Varnai P, Szentpetery Z, Knight Z, Shokat KM, Balla T. 2008. Maintenance of hormone-sensitive phosphoinositide pools in the plasma membrane requires phosphatidylinositol 4-kinase III $\alpha$. Mol Biol Cell 19: $711-721$.

Bao H, Reist NE, Zhang B. 2008. The Drosophila epsin 1 is required for ubiquitin-dependent synaptic growth and function but not for synaptic vesicle recycling. Traffic 9: 2190-2205.

Bashkirov PV, Akimov SA, Evseev AI, Schmid SL, Zimmerberg J, Frolov VA. 2008. GTPase cycle of dynamin is coupled to membrane squeeze and release, leading to spontaneous fission. Cell 135: 1276-1286.

Beck KA, Keen JH. 1991. Interaction of phosphoinositide cycle intermediates with the plasma membrane-associated clathrin assembly protein AP-2. J Biol Chem 266: 4442-4447.

Bednarek SY, Orci L, Schekman R. 1996. Traffic COPs and the formation of vesicle coats. Trends Cell Biol 6: 468473.

Betz WJ, Bewick GS. 1992. Optical analysis of synaptic vesicle recycling at the frog neuromuscular junction. Science 255: $200-203$.

Blondeau F, Ritter B, Allaire PD, Wasiak S, Girard M, Hussain NK, Angers A, Legendre-Guillemin V, Roy L, Boismenu D, et al. 2004. Tandem MS analysis of brain clathrin-coated vesicles reveals their critical involvement in synaptic vesicle recycling. Proc Natl Acad Sci 101: $3833-$ 3838.

Bloom O, Evergren E, Tomilin N, Kjaerulff O, Low P, Brodin L, Pieribone VA, Greengard P, Shupliakov O. 2003. 
Colocalization of synapsin and actin during synaptic vesicle recycling. J Cell Biol 161: 737-747.

Bonifacino JS, Traub LM. 2003. Signals for sorting of transmembrane proteins to endosomes and lysosomes. Annu Rev Biochem 72: 395-447.

Boucrot E, Pick A, Camdere G, Liska N, Evergren E, McMahon HT, Kozlov MM. 2012. Membrane fission is promoted by insertion of amphipathic helices and is restricted by crescent BAR domains. Cell 149: 124-136.

Boulant S, Kural C, Zeeh JC, Ubelmann F, Kirchhausen T. 2011. Actin dynamics counteract membrane tension during clathrin-mediated endocytosis. Nat Cell Biol 13: 1124-1131.

Bourne J, Morgan JR, Pieribone VA. 2006. Actin polymerization regulates clathrin coat maturation during early stages of synaptic vesicle recycling at lamprey synapses. J Comp Neurol 497: 600-609.

Brown HM, Van Epps HA, Goncharov A, Grant BD, Jin Y. 2009. The JIP3 scaffold protein UNC-16 regulates RAB-5 dependent membrane trafficking at $C$. elegans synapses. Dev Neurobiol 69: 174-190.

Bu W, Lim KB, Yu YH, Chou AM, Sudhaharan T, Ahmed S 2010. Cdc42 interaction with $\mathrm{N}$-wasp and toca-1 regulates membrane tubulation, vesicle formation and vesicle motility: Implications for endocytosis. PLoS ONE 5.

Burston HE, Maldonado-Baez L, Davey M, Montpetit B, Schluter C, Wendland B, Conibear E. 2009. Regulators of yeast endocytosis identified by systematic quantitative analysis. J Cell Biol 185: 1097-1110.

Cao H, Garcia F, McNiven MA. 1998. Differential distribution of dynamin isoforms in mammalian cells. Mol Biol Cell 9: 2595-2609.

Ceccarelli B, Hurlbut WP. 1980. $\mathrm{Ca}^{2+}$-dependent recycling of synaptic vesicles at the frog neuromuscular junction. $J$ Cell Biol 87: 297-303.

Ceccarelli B, Hurlbut WP, Mauro A. 1973. Turnover of transmitter and synaptic vesicles at the frog neuromuscular junction. J Cell Biol 57: 499-524.

Chang-Ileto B, Frere SG, Chan RB, Voronov SV, Roux A, Di Paolo G. 2010. Synaptojanin 1-mediated PI(4,5)P(2) hydrolysis is modulated by membrane curvature and facilitates membrane fission. Dev Cell 20: 206-218.

Chappie JS, Acharya S, Leonard M, Schmid SL, Dyda F. 2010. G domain dimerization controls dynamin's assembly-stimulated GTPase activity. Nature 465: 435-440.

Chappie JS, Mears JA, Fang S, Leonard M, Schmid SL, Milligan RA, Hinshaw JE, Dyda F. 2011. A pseudoatomic model of the dynamin polymer identifies a hydrolysisdependent powerstroke. Cell 147: 209-222.

Chen H, Slepnev VI, Di Fiore PP, De Camilli P. 1999. The interaction of epsin and Eps15 with the clathrin adaptor AP-2 is inhibited by mitotic phosphorylation and enhanced by stimulation-dependent dephosphorylation in nerve terminals. J Biol Chem 274: 3257-3260.

Chen H, Ko G, Zatti A, Di Giacomo G, Liu L, Raiteri E, Perucco E, Collesi C, Min W, Zeiss C, Cremona O. 2009. Embryonic arrest at midgestation and disruption of Notch signaling produced by the absence of both epsin 1 and epsin 2 in mice. Proc Natl Acad Sci 106: 1383813843 .
Clayton EL, Evans GJ, Cousin MA. 2008. Bulk synaptic vesicle endocytosis is rapidly triggered during strong stimulation. J Neurosci 28: 6627-6632.

Clayton EL, Anggono V, Smillie KJ, Chau N, Robinson PJ, Cousin MA. 2009. The phospho-dependent dynaminsyndapin interaction triggers activity-dependent bulk endocytosis of synaptic vesicles. J Neurosci 29: 7706-7717.

Conner SD, Schmid SL. 2002. Identification of an adaptorassociated kinase, AAK1, as a regulator of clathrin-mediated endocytosis. J Cell Biol 156: 921-929.

Conner SD, Schmid SL. 2003. Regulated portals of entry into the cell. Nature 422: 37-44.

Cousin MA, Robinson PJ. 2001. The dephosphins: Dephosphorylation by calcineurin triggers synaptic vesicle endocytosis. Trends Neurosci 24: 659-665.

Coyle IP, Koh YH, Lee WC, Slind J, Fergestad T, Littleton JT, Ganetzky B. 2004. Nervous wreck, an SH3 adaptor protein that interacts with Wsp, regulates synaptic growth in Drosophila. Neuron 41: 521-534.

Cremona O, De Camilli P. 2001. Phosphoinositides in membrane traffic at the synapse. J Cell Sci 114: 1041-1052.

Cremona O, Di Paolo G, Wenk MR, Luthi A, Kim WT, Takei K, Daniell L, Nemoto Y, Shears SB, Flavell RA, et al. 1999. Essential role of phosphoinositide metabolism in synaptic vesicle recycling. Cell 99: 179-188.

Dai J, Ting-Beall HP, Sheetz MP. 1997. The secretion-coupled endocytosis correlates with membrane tension changes in RBL 2H3 cells. J Gen Physiol 110: 1-10.

Dawson JC, Legg JA, Machesky LM. 2006. Bar domain proteins: A role in tubulation, scission and actin assembly in clathrin-mediated endocytosis. Trends Cell Biol 16: 493-498.

De Camilli P, Chen H, Hyman J, Panepucci E, Bateman A, Brunger AT. 2002. The ENTH domain. FEBS Lett 513: $11-18$.

de Hoop MJ, Huber LA, Stenmark H, Williamson E, Zerial M, Parton RG, Dotti CG. 1994. The involvement of the small GTP-binding protein Rab5a in neuronal endocytosis. Neuron 13: 11-22.

Di Paolo G, De Camilli P. 2006. Phosphoinositides in cell regulation and membrane dynamics. Nature 443: 651657.

Di Paolo G, Pellegrini L, Letinic K, Cestra G, Zoncu R, Voronov S, Chang S, Guo J, Wenk MR, De Camilli P. 2002a. Recruitment and regulation of phosphatidylinositol phosphate kinase type $1 \gamma$ by the FERM domain of talin. Nature 420: 85-89.

Di Paolo G, Sankaranarayanan S, Wenk MR, Daniell L, Perucco E, Caldarone BJ, Flavell R, Picciotto MR, Ryan TA, Cremona O, Camilli P. 2002b. Decreased synaptic vesicle recycling efficiency and cognitive deficits in amphiphysin 1 knockout mice. Neuron 33: 789-804.

Di Paolo G, Moskowitz HS, Gipson K, Wenk MR, Voronov S, Obayashi M, Flavell R, Fitzsimonds RM, Ryan TA, De Camilli P. 2004. Impaired PtdIns(4,5)P2 synthesis in nerve terminals produces defects in synaptic vesicle trafficking. Nature 431: 415-422.

Dickman DK, Horne JA, Meinertzhagen IA, Schwarz TL. 2005. A slowed classical pathway rather than kiss-andrun mediates endocytosis at synapses lacking synaptojanin and endophilin. Cell 123: 521-533. 
Dickman DK, Lu Z, Meinertzhagen IA, Schwarz TL. 2006. Altered synaptic development and active zone spacing in endocytosis mutants. Curr Biol 16: 591-598.

Diril MK, Wienisch M, Jung N, Klingauf J, Haucke V. 2006. Stonin 2 is an AP-2-dependent endocytic sorting adaptor for synaptotagmin internalization and recycling. Dev Cell 10: $233-244$.

Dittman JS, Kaplan JM. 2006. Factors regulating the abundance and localization of synaptobrevin in the plasma membrane. Proc Natl Acad Sci 103: 11399-11404.

Dittman J, Ryan TA. 2009. Molecular circuitry of endocytosis at nerve terminals. Annu Rev Cell Dev Biol 25: 133160.

Domin J, Gaidarov I, Smith ME, Keen JH, Waterfield MD. 2000. The class II phosphoinositide 3-kinase PI3K-C2 $\alpha$ is concentrated in the trans-Golgi network and present in clathrin-coated vesicles. J Biol Chem 275: 11943-11950.

Edeling MA, Smith C, Owen D. 2006. Life of a clathrin coat: Insights from clathrin and AP structures. Nat Rev Mol Cell Biol 7: 32-44.

Eggeling C, Ringemann C, Medda R, Schwarzmann G, Sandhoff K, Polyakova S, Belov VN, Hein B, von Middendorff C, Schonle A, et al. 2009. Direct observation of the nanoscale dynamics of membrane lipids in a living cell. Nature 457: 1159-1162.

Engqvist-Goldstein AE, Drubin DG. 2003. Actin assembly and endocytosis: From yeast to mammals. Annu Rev Cell Dev Biol 19: 287-332.

Erdmann KS, Mao Y, McCrea HJ, Zoncu R, Lee S, Paradise S, Modregger J, Biemesderfer D, Toomre D, De Camilli P. 2007. A role of the Lowe syndrome protein OCRL in early steps of the endocytic pathway. Dev Cell 13: 377-390.

Evergren E, Gad H, Walther K, Sundborger A, Tomilin N, Shupliakov O. 2007. Intersectin is a negative regulator of dynamin recruitment to the synaptic endocytic zone in the central synapse. J Neurosci 27: 379-390.

Faelber K, Posor Y, Gao S, Held M, Roske Y, Schulze D, Haucke V, Noe F, Daumke O. 2011. Crystal structure of nucleotide-free dynamin. Nature 477: 556-560.

Farsad K, De Camilli P. 2003. Mechanisms of membrane deformation. Curr Opin Cell Biol 15: 372-381.

Farsad K, Ringstad N, Takei K, Floyd SR, Rose K, De Camilli P. 2001. Generation of high curvature membranes mediated by direct endophilin bilayer interactions. J Cell Biol 155: $193-200$.

Faundez V, Horng JT, Kelly RB. 1998. A function for the AP3 coat complex in synaptic vesicle formation from endosomes. Cell 93: 423-432.

Fei H, Grygoruk A, Brooks ES, Chen A, Krantz DE. 2008. Trafficking of vesicular neurotransmitter transporters. Traffic 9: 1425-1436.

Ferguson SM, De Camilli P. 2012. Dynamin, a membraneremodelling GTPase. Nat Rev Mol Cell Biol 13: 75-88.

Ferguson SM, Brasnjo G, Hayashi M, Wolfel M, Collesi C, Giovedi S, Raimondi A, Gong LW, Ariel P, Paradise S, et al. 2007. A selective activity-dependent requirement for dynamin 1 in synaptic vesicle endocytosis. Science 316: 570-574.

Ferguson SM, Raimondi A, Paradise S, Shen H, Mesaki K, Ferguson A, Destaing O, Ko G, Takasaki J, Cremona OEOT, Camilli P. 2009. Coordinated actions of actin and BAR proteins upstream of dynamin at endocytic clathrin-coated pits. Dev Cell 17: 811-822.

Fernandez-Alfonso T, Kwan R, Ryan TA. 2006. Synaptic vesicles interchange their membrane proteins with a large surface reservoir during recycling. Neuron 51: 179-186.

Fesce R, Grohovaz F, Valtorta F, Meldolesi J. 1994. Neurotransmitter release: Fusion or "kiss-and-run?" Trends Cell Biol 4: 1-4.

Fischer von Mollard G, Stahl B, Walch-Solimena C, Takei K, Daniels L, Khoklatchev A, De Camilli P, Sudhof TC, Jahn R. 1994. Localization of Rab5 to synaptic vesicles identifies endosomal intermediate in synaptic vesicle recycling pathway. Eur J Cell Biol 65: 319-326.

Ford MG, Pearse BM, Higgins MK, Vallis Y, Owen DJ, Gibson A, Hopkins CR, Evans PR, McMahon HT. 2001. Simultaneous binding of PtdIns(4,5)P2 and clathrin by AP180 in the nucleation of clathrin lattices on membranes. Science 291: 1051-1055.

Ford MG, Mills IG, Peter BJ, Vallis Y, Praefcke GJ, Evans PR, McMahon HT. 2002. Curvature of clathrin-coated pits driven by epsin. Nature 419: 361-366.

Ford MG, Jenni S, Nunnari J. 2011. The crystal structure of dynamin. Nature 477: 561-566.

Frost A, Perera R, Roux A, Spasov K, Destaing O, Egelman EH, De Camilli P, Unger VM. 2008. Structural basis of membrane invagination by F-BAR domains. Cell 132: 807-817.

Frost A, Unger VM, De Camilli P. 2009. The BAR domain superfamily: Membrane-molding macromolecules. Cell 137: 191-196.

Gad H, Low P, Zotova E, Brodin L, Shupliakov O. 1998. Dissociation between $\mathrm{Ca}^{2+}$-triggered synaptic vesicle exocytosis and clathrin-mediated endocytosis at a central synapse. Neuron 21: 607-616.

Gallop JL, Jao CC, Kent HM, Butler PJ, Evans PR, Langen R, McMahon HT. 2006. Mechanism of endophilin N-BAR domain-mediated membrane curvature. EMBO $J$ 25: 2898-2910.

Gasper R, Meyer S, Gotthardt K, Sirajuddin M, Wittinghofer A. 2009. It takes two to tango: Regulation of G proteins by dimerization. Nat Rev Mol Cell Biol 10: 423-429.

Glyvuk N, Tsytsyura Y, Geumann C, D'Hooge R, Huve J, Kratzke M, Baltes J, Boening D, Klingauf J, Schu P. 2010. AP-1/sigma1B-adaptin mediates endosomal synaptic vesicle recycling, learning and memory. EMBO J 29: $1318-1330$.

Gong LW, Di Paolo G, Diaz E, Cestra G, Diaz ME, Lindau M, De Camilli P, Toomre D. 2005. Phosphatidylinositol phosphate kinase type I $\gamma$ regulates dynamics of large dense-core vesicle fusion. Proc Natl Acad Sci 102: 5204-5209.

Graham TR. 2004. Flippases and vesicle-mediated protein transport. Trends Cell Biol 14: 670-677.

Granseth B, Odermatt B, Royle SJ, Lagnado L. 2006. Clathrin-mediated endocytosis is the dominant mechanism of vesicle retrieval at hippocampal synapses. Neuron 51: $773-786$.

Grill B, Bienvenut WV, Brown HM, Ackley BD, Quadroni M, Jin Y. 2007. C. elegans RPM-1 regulates axon termination 
and synaptogenesis through the Rab GEF GLO-4 and the Rab GTPase GLO-1. Neuron 55: 587-601.

Gu M, Schuske K, Watanabe S, Liu Q, Baum P, Garriga G, Jorgensen EM. 2008. ôç $\mu 2$ adaptin facilitates but is not essential for synaptic vesicle recycling in Caenorhabditis elegans. J Cell Biol 183: 881-892.

Guan R, Dai H, Harrison SC, Kirchhausen T. 2010. Structure of the PTEN-like region of auxilin, a detector of clathrincoated vesicle budding. Structure 18: 1191-1198.

Guo S, Stolz LE, Lemrow SM, York JD. 1999. SAC1-like domains of yeast SAC1, INP52, and INP53 and of human synaptojanin encode polyphosphoinositide phosphatases. J Biol Chem 274: 12990-12995.

Guo J, Wenk MR, Pellegrini L, Onofri F, Benfenati F, De Camilli P. 2003. Phosphatidylinositol 4-kinase type II $\alpha$ is responsible for the phosphatidylinositol 4-kinase activity associated with synaptic vesicles. Proc Natl Acad Sci 100: $3995-4000$

Harata NC, Choi S, Pyle JL, Aravanis AM, Tsien RW. 2006. Frequency-dependent kinetics and prevalence of kissand-run and reuse at hippocampal synapses studied with novel quenching methods. Neuron 49: 243-256.

Haucke V, De Camilli P. 1999. AP-2 recruitment to synaptotagmin stimulated by tyrosine-based endocytic motifs. Science 285: 1268-1271.

Hayashi M, Raimondi A, O’Toole E, Paradise S, Collesi C, Cremona O, Ferguson SM, De Camilli P. 2008. Cell- and stimulus-dependent heterogeneity of synaptic vesicle endocytic recycling mechanisms revealed by studies of dynamin 1-null neurons. Proc Natl Acad Sci 105: 2175 2180 .

He L, Wu LG. 2007. The debate on the kiss-and-run fusion at synapses. Trends Neurosci 30: 447-455.

He G, Gupta S, Yi M, Michaely P, Hobbs HH, Cohen JC. 2002. ARH is a modular adaptor protein that interacts with the LDL receptor, clathrin, and AP-2.J Biol Chem 277: 44044-44049.

He L, Wu XS, Mohan R, Wu LG. 2006. Two modes of fusion pore opening revealed by cell-attached recordings at a synapse. Nature 444: 102-105.

Heerssen H, Fetter RD, Davis GW. 2008. Clathrin dependence of synaptic-vesicle formation at the Drosophila neuromuscular junction. Curr Biol 18: 401-409.

Helenius A, Mellman I, Wall D, Hubbard A. 1983. Endosomes. Trends Biochem Sci 8: 245-250.

Henne WM, Boucrot E, Meinecke M, Evergren E, Vallis Y, Mittal R, McMahon HT. 2010. FCHo proteins are nucleators of clathrin-mediated endocytosis. Science 328: 1281-1284.

Heuser J. 1989. The role of coated vesicles in recycling of synaptic vesicle membrane. Cell Biol Int Rep 13: $1063-$ 1076.

Heuser JE, Reese TS. 1973. Evidence for recycling of synaptic vesicle membrane during transmitter release at the frog neuromuscular junction. J Cell Biol 57: 315-344.

Hinshaw JE, Schmid SL. 1995. Dynamin self-assembles into rings suggesting a mechanism for coated vesicle budding. Nature 374: 190-192.

Holroyd P, Lang T, Wenzel D, De Camilli P, Jahn R. 2002. Imaging direct, dynamin-dependent recapture of fusing secretory granules on plasma membrane lawns from PC12 cells. Proc Natl Acad Sci 99: 16806-16811.

Holt M, Cooke A, Wu MM, Lagnado L. 2003. Bulk membrane retrieval in the synaptic terminal of retinal bipolar cells. J Neurosci 23: 1329-1339.

Holtzman E, Freeman AR, Kashner LA. 1971. Stimulationdependent alterations in peroxidase uptake at lobster neuromuscular junctions. Science 173: 733-736.

Hoopmann P, Punge A, Barysch SV, Westphal V, Buckers J, Opazo F, Bethani I, Lauterbach MA, Hell SW, Rizzoli SO. 2010. Endosomal sorting of readily releasable synaptic vesicles. Proc Natl Acad Sci 107: 19055-19060.

Hosoi N, Holt M, Sakaba T. 2009. Calcium dependence of exo- and endocytotic coupling at a glutamatergic synapse. Neuron 63: 216-229.

Hua Y, Sinha R, Thiel CS, Schmidt R, Huve J, Martens H, Hell SW, Egner A, Klingauf J. 2011. A readily retrievable pool of synaptic vesicles. Nat Neurosci 14: 833-839.

Hull C, von Gersdorff H. 2004. Fast endocytosis is inhibited by GABA-mediated chloride influx at a presynaptic terminal. Neuron 44: 469-482.

Hussain NK, Jenna S, Glogauer M, Quinn CC, Wasiak S, Guipponi M, Antonarakis SE, Kay BK, Stossel TP, Lamarche-Vane N, et al. 2001. Endocytic protein intersectin-l regulates actin assembly via Cdc 42 and N-WASP. Nat Cell Biol 3: 927-932.

Itoh T, De Camilli P. 2006. BAR, F-BAR (EFC) and ENTH/ ANTH domains in the regulation of membrane-cytosol interfaces and membrane curvature. Biochim Biophys Acta 1761: 897-912.

Itoh T, Erdmann KS, Roux A, Habermann B, Werner H, De Camilli P. 2005. Dynamin and the actin cytoskeleton cooperatively regulate plasma membrane invagination by BAR and F-BAR proteins. Dev Cell 9: 791-804.

Jackson LP, Kelly BT, McCoy AJ, Gaffry T, James LC, Collins BM, Honing S, Evans PR, Owen DJ. 2010. A large-scale conformational change couples membrane recruitment to cargo binding in the AP2 clathrin adaptor complex. Cell 141: 1220-1229.

Jakobsson J, Gad H, Andersson F, Low P, Shupliakov O, Brodin L. 2008. Role of epsin 1 in synaptic vesicle endocytosis. Proc Natl Acad Sci 105: 6445-6450.

Jakobsson J, Ackermann F, Andersson F, Larhammar D, Low P, Brodin L. 2011. Regulation of synaptic vesicle budding and dynamin function by an EHD ATPase. J Neurosci 31: 13972-13980.

Jin Y, Garner CC. 2008. Molecular mechanisms of presynaptic differentiation. Annu Rev Cell Dev Biol 24: 237-262.

Jockusch WJ, Praefcke GJ, McMahon HT, Lagnado L. 2005. Clathrin-dependent and clathrin-independent retrieval of synaptic vesicles in retinal bipolar cells. Neuron 46: 869-878.

Jung N, Haucke V. 2007. Clathrin-mediated endocytosis at synapses. Traffic 8: 1129-1136.

Kadota K, Kadota T. 1973. Isolation of coated vesicles, plain synaptic vesicles, and flocculent material from a crude synaptosome fraction of guinea pig whole brain. $J$ Cell Biol 58: 135-151.

Kahlfeldt N, Vahedi-Faridi A, Koo SJ, Schafer JG, Krainer G, Keller S, Saenger W, Krauss M, Haucke V. 2010. Molecular 
basis for association of PIPKI $\gamma$-p90 with clathrin adaptor AP-2. J Biol Chem 285: 2734-2749.

Kaksonen M, Sun Y, Drubin DG. 2003. A pathway for association of receptors, adaptors, and actin during endocytic internalization. Cell 115: 475-487.

Kaksonen M, Toret CP, Drubin DG. 2005. A modular design for the clathrin- and actin-mediated endocytosis machinery. Cell 123: 305-320.

Kaksonen M, Toret CP, Drubin DG. 2006. Harnessing actin dynamics for clathrin-mediated endocytosis. Nat Rev Mol Cell Biol 7: 404-414.

Kasprowicz J, Kuenen S, Miskiewicz K, Habets RL, Smitz L, Verstreken P. 2008. Inactivation of clathrin heavy chain inhibits synaptic recycling but allows bulk membrane uptake. J Cell Biol 182: 1007-1016.

Kelly LE, Phillips AM. 2005. Molecular and genetic characterization of the interactions between the Drosophila stoned-B protein and DAP-160 (intersectin). Biochem J 388 (Pt 1): 195-204.

Kessels MM, Qualmann B. 2002. Syndapins integrate NWASP in receptor-mediated endocytosis. EMBO J 21: 6083-6094.

Kessels MM, Qualmann B. 2004. The syndapin protein family: Linking membrane trafficking with the cytoskeleton. J Cell Sci 117 (Pt 15):: 3077-3086.

Kim SH, Ryan TA. 2009. Synaptic vesicle recycling at CNS snapses without AP-2. J Neurosci 29: 3865-3874.

Kirchhausen T. 2000a. Clathrin. Annu Rev Biochem 69: 699_ 727.

Kirchhausen T. 2000b. Three ways to make a vesicle. Nat Rev Mol Cell Biol 1: 187-198.

Kirchhausen T. 2009. Imaging endocytic clathrin structures in living cells. Trends Cell Biol 19: 596-605.

Klyachko VA, Jackson MB. 2002. Capacitance steps and fusion pores of small and large-dense-core vesicles in nerve terminals. Nature 418: 89-92.

Ko G, Paradise S, Chen H, Graham M, Vecchi M, Bianchi F, Cremona O, Di Fiore PP, De Camilli P. 2010. Selective high-level expression of epsin 3 in gastric parietal cells, where it is localized at endocytic sites of apical canaliculi. Proc Natl Acad Sci 107: 21511-21516.

Koch D, Spiwoks-Becker I, Sabanov V, Sinning A, Dugladze T, Stellmacher A, Ahuja R, Grimm J, Schuler S, Muller A, et al. 2011. Proper synaptic vesicle formation and neuronal network activity critically rely on syndapin I. EMBO J 30: 4955-4969.

Koenig JH, Ikeda K. 1989. Disappearance and reformation of synaptic vesicle membrane upon transmitter release observed under reversible blockage of membrane retrieval. J Neurosci 9: 3844-3860.

Koh TW, Verstreken P, Bellen HJ. 2004. Dap160/intersectin acts as a stabilizing scaffold required for synaptic development and vesicle endocytosis. Neuron 43: 193-205.

Koh TW, Korolchuk VI, Wairkar YP, Jiao W, Evergren E, Pan H, Zhou Y, Venken KJ, Shupliakov O, Robinson IM, et al. 2007. Eps15 and Dap160 control synaptic vesicle membrane retrieval and synapse development. J Cell Biol 178: 309-322.

Koo SJ, Markovic S, Puchkov D, Mahrenholz CC, BecerenBraun F, Maritzen T, Dernedde J, Volkmer R, Oschkinat H, Haucke V. 2011. SNARE motif-mediated sorting of synaptobrevin by the endocytic adaptors clathrin assembly lymphoid myeloid leukemia (CALM) and AP180 at synapses. Proc Natl Acad Sci 108: 13540-13545.

Kraszewski K, Mundigl O, Daniell L, Verderio C, Matteoli M, De Camilli P. 1995. Synaptic vesicle dynamics in living cultured hippocampal neurons visualized with CY3-conjugated antibodies directed against the lumenal domain of synaptotagmin. J Neurosci 15: 4328-4342.

Krauss M, Kukhtina V, Pechstein A, Haucke V. 2006. Stimulation of phosphatidylinositol kinase type I-mediated phosphatidylinositol (4,5)-bisphosphate synthesis by AP- $2 \mu$-cargo complexes. Proc Natl Acad Sci 103: 11934-11939.

Lariccia V, Fine M, Magi S, Lin MJ, Yaradanakul A, Llaguno MC, Hilgemann DW. 2010. Massive calcium-activated endocytosis without involvement of classical endocytic proteins. J Gen Physiol 137: 111-132.

Lee A, Frank DW, Marks MS, Lemmon MA. 1999. Dominant-negative inhibition of receptor-mediated endocytosis by a dynamin-1 mutant with a defective pleckstrin homology domain. Curr Biol 9: 261-264.

Lee SY, Wenk MR, Kim Y, Nairn AC, De Camilli P. 2004. Regulation of synaptojanin 1 by cyclin-dependent kinase 5 at synapses. Proc Natl Acad Sci 101: 546-551.

Lee SY, Voronov S, Letinic K, Nairn AC, Di Paolo G, De Camilli P. 2005. Regulation of the interaction between PIPKI $\gamma$ and talin by proline-directed protein kinases. $J$ Cell Biol 168: 789-799.

Lin FT, Krueger KM, Kendall HE, Daaka Y, Fredericks ZL, Pitcher JA, Lefkowitz RJ. 1997. Clathrin-mediated endocytosis of the $\beta$-adrenergic receptor is regulated by phosphorylation/dephosphorylation of $\beta$-arrestin1. J Biol Chem 272: 31051-31057.

Ling K, Doughman RL, Firestone AJ, Bunce MW, Anderson RA. 2002. Type I $\gamma$ phosphatidylinositol phosphate kinase targets and regulates focal adhesions. Nature 420: 89-93.

Liu J, Sun Y, Drubin DG, Oster GF. 2009. The mechanochemistry of endocytosis. PLoS Biol 7: e1000204.

Liu JP, Sim AT, Robinson PJ. 1994. Calcineurin inhibition of dynamin I GTPase activity coupled to nerve terminal depolarization. Science 265: 970-973.

Lou X, Paradise S, Ferguson SM, De Camilli P. 2008. Selective saturation of slow endocytosis at a giant glutamatergic central synapse lacking dynamin 1. Proc Natl Acad Sci 105: 17555-17560.

Lou X, Fan F, Messa M, Raimondi A, Wu Y, Looger LL, Ferguson SM, De Camilli P. 2012. Reduced release probability prevents vesicle depletion and transmission failure at dynamin mutant synapses. Proc Natl Acad Sci 109: E515-E523.

Low HH, Lowe J. 2010. Dynamin architecture-From monomer to polymer. Curr Opin Struct Biol 20: 791798.

Malacombe M, Ceridono M, Calco V, Chasserot-Golaz S, McPherson PS, Bader MF, Gasman S. 2006. Intersectin$1 \mathrm{~L}$ nucleotide exchange factor regulates secretory granule exocytosis by activating Cdc42. EMBO J 25: 3494-3503.

Mao Y, Balkin DM, Zoncu R, Erdmann KS, Tomasini L, Hu F, Jin MM, Hodsdon ME, De Camilli P. 2009. A PH domain within OCRL bridges clathrin-mediated 
membrane trafficking to phosphoinositide metabolism. EMBO J 28: 1831-1842.

Marat AL, Dokainish H, McPherson PS. 2010. DENN domain proteins: Regulators of Rab GTPases. J Biol Chem 286: $13791-13800$.

Marie B, Sweeney ST, Poskanzer KE, Roos J, Kelly RB, Davis GW. 2004. Dap160/intersectin scaffolds the periactive zone to achieve high-fidelity endocytosis and normal synaptic growth. Neuron 43: 207-219.

Martens H, Weston MC, Boulland JL, Gronborg M, Grosche J, Kacza J, Hoffmann A, Matteoli M, Takamori S, Harkany T, et al. 2008. Unique luminal localization of VGAT$\mathrm{C}$ terminus allows for selective labeling of active cortical GABAergic synapses. J Neurosci 28: 13125-13131.

Masuda M, Takeda S, Sone M, Ohki T, Mori H, Kamioka Y, Mochizuki N. 2006. Endophilin BAR domain drives membrane curvature by two newly identified structurebased mechanisms. EMBO J 25: 2889-2897.

Matteoli M, Takei K, Perin MS, Sudhof TC, De Camilli P. 1992. Exo-endocytotic recycling of synaptic vesicles in developing processes of cultured hippocampal neurons. J Cell Biol 117: 849-861.

Maycox PR, Link E, Reetz A, Morris SA, Jahn R. 1992. Clathrin-coated vesicles in nervous tissue are involved primarily in synaptic vesicle recycling. J Cell Biol 118: 1379-1388.

McMahon HT, Boucrot E. 2011. Molecular mechanism and physiological functions of clathrin-mediated endocytosis. Nat Rev Mol Cell Biol 12: 517-533.

McPherson PS. 2010. Proteomic analysis of clathrin-coated vesicles. Proteomics 10: 4025-4039.

McPherson PS, Takei K, Schmid SL, De Camilli P. 1994. p145, a major Grb2-binding protein in brain, is co-localized with dynamin in nerve terminals where it undergoes activity-dependent dephosphorylation. J Biol Chem 269: 30132-30139.

McPherson PS, Garcia EP, Slepnev VI, David C, Zhang X, Grabs D, Sossin WS, Bauerfeind R, Nemoto Y, De Camilli P. 1996. A presynaptic inositol-5-phosphatase. Nature 379: 353-357.

Mears JA, Ray P, Hinshaw JE. 2007. A corkscrew model for dynamin constriction. Structure 15: 1190-1202.

Mellman I. 1996. Endocytosis and molecular sorting. Annu Rev Cell Dev Biol 12: 575-625.

Merrifield CJ, Feldman ME, Wan L, Almers W. 2002. Imaging actin and dynamin recruitment during invagination of single clathrin-coated pits. Nat Cell Biol 4: 691-698.

Merrifield CJ, Perrais D, Zenisek D. 2005. Coupling between clathrin-coated-pit invagination, cortactin recruitment, and membrane scission observed in live cells. Cell 121: 593-606.

Meunier FA, Nguyen TH, Colasante C, Luo F, Sullivan RK, Lavidis NA, Molgo J, Meriney SD, Schiavo G. 2010. Sustained synaptic-vesicle recycling by bulk endocytosis contributes to the maintenance of high-rate neurotransmitter release stimulated by glycerotoxin. J Cell Sci 123: 1131-1140.

Miaczynska M, Pelkmans L, Zerial M. 2004. Not just a sink: Endosomes in control of signal transduction. Curr Opin Cell Biol 16: 400-406.
Miesenbock G, De Angelis DA, Rothman JE. 1998. Visualizing secretion and synaptic transmission with $\mathrm{pH}$-sensitive green fluorescent proteins. Nature 394: 192-195.

Miki H, Miura K, Takenawa T. 1996. N-WASP, a novel actindepolymerizing protein, regulates the cortical cytoskeletal rearrangement in a PIP2-dependent manner downstream of tyrosine kinases. EMBO J 15: 5326-5335.

Miki H, Sasaki T, Takai Y, Takenawa T. 1998. Induction of filopodium formation by a WASP-related actin-depolymerizing protein N-WASP. Nature 391: 93-96.

Miller TM, Heuser JE. 1984. Endocytosis of synaptic vesicle membrane at the frog neuromuscular junction. J Cell Biol 98: 685-698.

Miller SE, Sahlender DA, Graham SC, Honing S, Robinson MS, Peden AA, Owen DJ. 2011. The molecular basis for the endocytosis of small R-SNAREs by the clathrin adaptor CALM. Cell 147: 1118-1131.

Milosevic I, Sorensen JB, Lang T, Krauss M, Nagy G, Haucke V, Jahn R, Neher E. 2005. Plasmalemmal phosphatidylinositol-4,5-bisphosphate level regulates the releasable vesicle pool size in chromaffin cells. J Neurosci 25: 2557-2565.

Milosevic I, Giovedi S, Lou X, Raimondi A, Collesi C, Shen H, Paradise S, O’Toole E, Ferguson S, Cremona O, et al. 2011. Recruitment of endophilin to clathrin-coated pit necks is required for efficient vesicle uncoating after fission. Neuron 72: 587-601.

Mishra SK, Keyel PA, Edeling MA, Dupin AL, Owen DJ, Traub LM. 2005. Functional dissection of an AP-2 $\beta 2$ appendage-binding sequence within the autosomal recessive hypercholesterolemia protein. J Biol Chem 280: 19270-19280.

Montesinos ML, Castellano-Munoz M, Garcia-Junco-Clemente P, Fernandez-Chacon R. 2005. Recycling and EH domain proteins at the synapse. Brain Res Brain Res Rev 49: $416-428$.

Morgan JR, Prasad K, Hao W, Augustine GJ, Lafer EM. 2000 A conserved clathrin assembly motif essential for synaptic vesicle endocytosis. J Neurosci 20: 8667-8676.

Morris SM, Cooper JA. 2001. Disabled-2 colocalizes with the LDLR in clathrin-coated pits and interacts with AP-2. Traffic 2: 111-123.

Murthy VN, Stevens CF. 1998. Synaptic vesicles retain their identity through the endocytic cycle. Nature 392: $497-$ 501.

Nakano-Kobayashi A, Yamazaki M, Unoki T, Hongu T, Murata C, Taguchi R, Katada T, Frohman MA, Yokozeki T, Kanaho Y. 2007. Role of activation of PIP5K $\gamma 661$ by AP-2 complex in synaptic vesicle endocytosis. $E M B O J$ 26: $1105-1116$

Nakatsu F, Okada M, Mori F, Kumazawa N, Iwasa H, Zhu G, Kasagi Y, Kamiya H, Harada A, Nishimura K, et al. 2004. Defective function of GABA-containing synaptic vesicles in mice lacking the AP-3B clathrin adaptor. $J$ Cell Biol 167: $293-302$.

Nakatsu F, Perera RM, Lucast L, Zoncu R, Domin J, Gertler FB, Toomre D, De Camilli P. 2010. The inositol 5-phosphatase SHIP2 regulates endocytic clathrin-coated pit dynamics. J Cell Biol 190: 307-315.

Neher E, Marty A. 1982. Discrete changes of cell membrane capacitance observed under conditions of enhanced 
secretion in bovine adrenal chromaffin cells. Proc Natl Acad Sci 79: 6712-6716.

Neves G, Gomis A, Lagnado L. 2001. Calcium influx selects the fast mode of endocytosis in the synaptic terminal of retinal bipolar cells. Proc Natl Acad Sci 98: 15282-15287.

Newell-Litwa K, Salazar G, Smith Y, Faundez V. 2009. Roles of BLOC-1 and adaptor protein-3 complexes in cargo sorting to synaptic vesicles. Mol Biol Cell 20: 1441-1453.

Newton AJ, Kirchhausen T, Murthy VN. 2006. Inhibition of dynamin completely blocks compensatory synaptic vesicle endocytosis. Proc Natl Acad Sci 103: 17955-17960.

Nicholson-Tomishima K, Ryan TA. 2004. Kinetic efficiency of endocytosis at mammalian CNS synapses requires synaptotagmin I. Proc Natl Acad Sci 101: 16648-16652.

Nonet ML, Holgado AM, Brewer F, Serpe CJ, Norbeck BA, Holleran J, Wei L, Hartwieg E, Jorgensen EM, Alfonso A. 1999. UNC-11, a Caenorhabditis elegans AP180 homologue, regulates the size and protein composition of synaptic vesicles. Mol Biol Cell 10: 2343-2360.

Okamoto PM, Herskovits JS, Vallee RB. 1997. Role of the basic, proline-rich region of dynamin in Src homology 3 domain binding and endocytosis. J Biol Chem 272: 11629-11635.

Okamoto M, Schoch S, Sudhof TC. 1999. EHSH1/intersectin, a protein that contains $\mathrm{EH}$ and $\mathrm{SH} 3$ domains and binds to dynamin and SNAP-25. A protein connection between exocytosis and endocytosis? J Biol Chem 274: 18446-18454.

Osborne SL, Meunier FA, Schiavo G. 2001. Phosphoinositides as key regulators of synaptic function. Neuron 32: 9-12.

Owen DJ, Collins BM, Evans PR. 2004. Adaptors for clathrin coats: Structure and function. Annu Rev Cell Dev Biol 20: $153-191$.

Paillart C, Li J, Matthews G, Sterling P. 2003. Endocytosis and vesicle recycling at a ribbon synapse. J Neurosci 23: 4092-4099.

Pant S, Sharma M, Patel K, Caplan S, Carr CM, Grant BD. 2009. AMPH-1/Amphiphysin/Bin1 functions with RME-1/Ehd1 in endocytic recycling. Nat Cell Biol 11: 1399-1410.

Parsons TD, Lenzi D, Almers W, Roberts WM. 1994. Calcium-triggered exocytosis and endocytosis in an isolated presynaptic cell: Capacitance measurements in saccular hair cells. Neuron 13: 875-883.

Pavlos NJ, Gronborg M, Riedel D, Chua JJ, Boyken J, Kloepper TH, Urlaub H, Rizzoli SO, Jahn R. 2010. Quantitative analysis of synaptic vesicle Rabs uncovers distinct yet overlapping roles for Rab3a and Rab27b in $\mathrm{Ca}^{2+}$-triggered exocytosis. J Neurosci 30: 13441-13453.

Pearse BM. 1975. Coated vesicles from pig brain: Purification and biochemical characterization. J Mol Biol 97: 93-98.

Pechstein A, Bacetic J, Vahedi-Faridi A, Gromova K, Sundborger A, Tomlin N, Krainer G, Vorontsova O, Schafer JG, Owe SG, et al. 2010a. Regulation of synaptic vesicle recycling by complex formation between intersectin 1 and the clathrin adaptor complex AP2. Proc Natl Acad Sci 107: 4206-4211.
Pechstein A, Shupliakov O, Haucke V. 2010b. Intersectin 1: A versatile actor in the synaptic vesicle cycle. Biochem Soc Trans 38 (Pt 1): 181-186.

Perera RM, Zoncu R, Lucast L, De Camilli P, Toomre D. 2006. Two synaptojanin 1 isoforms are recruited to clathrin-coated pits at different stages. Proc Natl Acad Sci 103: 19332-19337.

Peter BJ, Kent HM, Mills IG, Vallis Y, Butler PJ, Evans PR, McMahon HT. 2004. BAR domains as sensors of membrane curvature: The amphiphysin BAR structure. Science 303: 495-499.

Pieribone VA, Shupliakov O, Brodin L, Hilfiker-Rothenfluh S, Czernik AJ, Greengard P. 1995. Distinct pools of synaptic vesicles in neurotransmitter release. Nature 375: 493-497.

Polo S, Confalonieri S, Salcini AE, Di Fiore PP. 2003. EH and UIM: Endocytosis and more. Sci STKE 2003: re17.

Praefcke GJ, McMahon HT. 2004. The dynamin superfamily: Universal membrane tubulation and fission molecules? Nat Rev Mol Cell Biol 5: 133-147.

Pucadyil TJ, Schmid SL. 2008. Real-time visualization of dynamin-catalyzed membrane fission and vesicle release. Cell 135: 1263-1275.

Raimondi A, Ferguson SM, Lou X, Armbruster M, Paradise S, Giovedi S, Messa M, Kono N, Takasaki J, Cappello V, et al. 2011. Overlapping role of dynamin isoforms in synaptic vesicle endocytosis. Neuron 70: 1100-1114.

Ramirez DM, Khvotchev M, Trauterman B, Kavalali ET. 2012. Vtila identifies a vesicle pool that preferentially recycles at rest and maintains spontaneous neurotransmission. Neuron 73: 121-134.

Rikhy R, Kumar V, Mittal R, Krishnan KS. 2002. Endophilin is critically required for synapse formation and function in Drosophila melanogaster. J Neurosci 22: $7478-$ 7484.

Ringstad N, Gad H, Low P, Di Paolo G, Brodin L, Shupliakov O, De Camilli P. 1999. Endophilin/SH3p4 is required for the transition from early to late stages in clathrinmediated synaptic vesicle endocytosis. Neuron 24: 143154.

Ringstad N, Nemoto Y, De Camilli P. 2001. Differential expression of endophilin 1 and 2 dimers at central nervous system synapses. J Biol Chem 276: 40424-40430.

Rodal AA, Motola-Barnes RN, Littleton JT. 2008. Nervous wreck and Cdc42 cooperate to regulate endocytic actin assembly during synaptic growth. J Neurosci 28: 83168325.

Rose S, Malabarba MG, Krag C, Schultz A, Tsushima H, Di Fiore PP, Salcini AE. 2007. Caenorhabditis elegans intersectin: A synaptic protein regulating neurotransmission. Mol Biol Cell 18: 5091-5099.

Rothman JE. 1994. Mechanisms of intracellular protein transport. Nature 372: 55-63.

Roux A, Uyhazi K, Frost A, De Camilli P. 2006. GTP-dependent twisting of dynamin implicates constriction and tension in membrane fission. Nature 441: 528-531.

Roux A, Koster G, Lenz M, Sorre B, Manneville JB, Nassoy P, Bassereau P. 2010. Membrane curvature controls dynamin polymerization. Proc Natl Acad Sci 107: 4141-4146. 
Ryan TA, Smith SJ, Reuter H. 1996. The timing of synaptic vesicle endocytosis. Proc Natl Acad Sci 93: 5567-5571.

Ryan TA, Reuter H, Smith SJ. 1997. Optical detection of a quantal presynaptic membrane turnover. Nature 388: $478-482$.

Saffarian S, Cocucci E, Kirchhausen T. 2009. Distinct dynamics of endocytic clathrin-coated pits and coated plaques. PLoS Biol 7: e1000191.

Salazar MA, Kwiatkowski AV, Pellegrini L, Cestra G, Butler MH, Rossman KL, Serna DM, Sondek J, Gertler FB, De Camilli P. 2003. Tuba, a novel protein containing bin/ amphiphysin/Rvs and Dbl homology domains, links dynamin to regulation of the actin cytoskeleton. J Biol Chem 278: $49031-49043$.

Salcini AE, Hilliard MA, Croce A, Arbucci S, Luzzi P, Tacchetti C, Daniell L, De Camilli P, Pelicci PG, Di Fiore PP, et al. 2001. The Eps15 C. elegans homologue EHS-1 is implicated in synaptic vesicle recycling. Nat Cell Biol 3: $755-760$.

Sankaranarayanan S, Ryan TA. 2000. Real-time measurements of vesicle-SNARE recycling in synapses of the central nervous system. Nat Cell Biol 2: 197-204.

Sankaranarayanan S, Ryan TA. 2001. Calcium accelerates endocytosis of vSNAREs at hippocampal synapses. Nat Neurosci 4: 129-136.

Sankaranarayanan S, Atluri PP, Ryan TA. 2003. Actin has a molecular scaffolding, not propulsive, role in presynaptic function. Nat Neurosci 6: 127-135.

Sann S, Wang Z, Brown H, Jin Y. 2009. Roles of endosomal trafficking in neurite outgrowth and guidance. Trends Cell Biol 19: 317-324.

Sato K, Ernstrom GG, Watanabe S, Weimer RM, Chen CH, Sato M, Siddiqui A, Jorgensen EM, Grant BD. 2009. Differential requirements for clathrin in receptor-mediated endocytosis and maintenance of synaptic vesicle pools. Proc Natl Acad Sci 106: 1139-1144.

Schmid EM, McMahon HT. 2007. Integrating molecular and network biology to decode endocytosis. Nature 448: $883-888$.

Schuske KR, Richmond JE, Matthies DS, Davis WS, Runz S, Rube DA, van der Bliek AM, Jorgensen EM. 2003. Endophilin is required for synaptic vesicle endocytosis by localizing synaptojanin. Neuron 40: 749-762.

Scita G, Di Fiore PP. 2010. The endocytic matrix. Nature 463: 464-473.

Shen H, Ferguson SM, Dephoure N, Park R, Yang Y, Volpicelli-Daley L, Gygi S, Schlessinger J, De Camilli P. 2010. Constitutive activated Cdc42-associated kinase (Ack) phosphorylation at arrested endocytic clathrincoated pits of cells that lack dynamin. Mol Biol Cell 22: 493-502.

Shimada A, Niwa H, Tsujita K, Suetsugu S, Nitta K, Hanawa-Suetsugu K, Akasaka R, Nishino Y, Toyama M, Chen L, et al. 2007. Curved EFC/F-BAR-domain dimers are joined end to end into a filament for membrane invagination in endocytosis. Cell 129: 761-772.

Shupliakov O, Low P, Grabs D, Gad H, Chen H, David C, Takei K, De Camilli P, Brodin L. 1997. Synaptic vesicle endocytosis impaired by disruption of dynamin-SH3 domain interactions. Science 276: 259-263.
Shupliakov O, Bloom O, Gustafsson JS, Kjaerulff O, Low P, Tomilin N, Pieribone VA, Greengard P, Brodin L. 2002. Impaired recycling of synaptic vesicles after acute perturbation of the presynaptic actin cytoskeleton. Proc Natl Acad Sci 99: 14476-14481.

Slepnev VI, De Camilli P. 2000. Accessory factors in clathrindependent synaptic vesicle endocytosis. Nat Rev Neurosci 1: $161-172$.

Slepnev VI, Ochoa GC, Butler MH, Grabs D, De Camilli P. 1998. Role of phosphorylation in regulation of the assembly of endocytic coat complexes. Science 281: 821-824.

Smith SM, Renden R, von Gersdorff H. 2008. Synaptic vesicle endocytosis: Fast and slow modes of membrane retrieval. Trends Neurosci 31: 559-568.

Sun JY, Wu LG. 2001. Fast kinetics of exocytosis revealed by simultaneous measurements of presynaptic capacitance and postsynaptic currents at a central synapse. Neuron 30: $171-182$.

Sun JY, Wu XS, Wu LG. 2002. Single and multiple vesicle fusion induce different rates of endocytosis at a central synapse. Nature 417: 555-559.

Szaszak M, Gaborik Z, Turu G, McPherson PS, Clark AJ, Catt KJ, Hunyady L. 2002. Role of the proline-rich domain of dynamin-2 and its interactions with Src homology 3 domains during endocytosis of the AT 1 angiotensin receptor. J Biol Chem 277: 21650-21656.

Tabares L, Ruiz R, Linares-Clemente P, Gaffield MA, Alvarez de Toledo G, Fernandez-Chacon R, Betz WJ. 2007. Monitoring synaptic function at the neuromuscular junction of a mouse expressing synaptopHluorin. J Neurosci 27: 5422-5430.

Takamori S, Holt M, Stenius K, Lemke EA, Gronborg M, Riedel D, Urlaub H, Schenck S, Brugger B, Ringler P, et al. 2006. Molecular anatomy of a trafficking organelle. Cell 127: $831-846$.

Takei K, McPherson PS, Schmid SL, De Camilli P. 1995. Tubular membrane invaginations coated by dynamin rings are induced by GTP- $\gamma \mathrm{S}$ in nerve terminals. Nature 374: $186-190$.

Takei K, Mundigl O, Daniell L, De Camilli P. 1996. The synaptic vesicle cycle: A single vesicle budding step involving clathrin and dynamin. J Cell Biol 133: 12371250.

Takei K, Slepnev VI, Haucke V, De Camilli P. 1999. Functional partnership between amphiphysin and dynamin in clathrin-mediated endocytosis. Nat Cell Biol 1: 33-39.

Takenawa T, Suetsugu S. 2007. The WASP-WAVE protein network: Connecting the membrane to the cytoskeleton. Nat Rev Mol Cell Biol 8: 37-48.

Tan TC, Valova VA, Malladi CS, Graham ME, Berven LA, Jupp OJ, Hansra G, McClure SJ, Sarcevic B, Boadle RA, et al. 2003. Cdk5 is essential for synaptic vesicle endocytosis. Nat Cell Biol 5: 701-710.

Taraska JW, Perrais D, Ohara-Imaizumi M, Nagamatsu S, Almers W. 2003. Secretory granules are recaptured largely intact after stimulated exocytosis in cultured endocrine cells. Proc Natl Acad Sci 100: 2070-2075.

Taylor MJ, Perrais D, Merrifield CJ. 2011. A high precision survey of the molecular dynamics of mammalian clathrin-mediated endocytosis. PLoS Biol 9: e1000604. 
Teng H, Lin MY, Wilkinson RS. 2007. Macroendocytosis and endosome processing in snake motor boutons. J Physiol 582 (Pt 1): 243-262.

Thieman JR, Mishra SK, Ling K, Doray B, Anderson RA, Traub LM. 2009. Clathrin regulates the association of PIPKI $\gamma 661$ with the AP-2 adaptor $\beta 2$ appendage. J Biol Chem 284: 13924-13939.

Tomizawa K, Sunada S, Lu YF, Oda Y, Kinuta M, Ohshima T, Saito T, Wei FY, Matsushita M, Li ST, et al. 2003. Cophosphorylation of amphiphysin I and dynamin I by Cdk5 regulates clathrin-mediated endocytosis of synaptic vesicles. J Cell Biol 163: 813-824.

Toret CP, Drubin DG. 2006. The budding yeast endocytic pathway. J Cell Sci 119 (Pt 22): 4585-4587.

Torri-Tarelli F, Haimann C, Ceccarelli B. 1987. Coated vesicles and pits during enhanced quantal release of acetylcholine at the neuromuscular junction. J Neurocytol 16: 205-214.

Traub LM. 2003. Sorting it out: AP-2 and alternate clathrin adaptors in endocytic cargo selection. J Cell Biol 163 203-208.

Tsujita K, Suetsugu S, Sasaki N, Furutani M, Oikawa T, Takenawa T. 2006. Coordination between the actin cytoskeleton and membrane deformation by a novel membrane tubulation domain of $\mathrm{PCH}$ proteins is involved in endocytosis. J Cell Biol 172: 269-279.

Vallis Y, Wigge P, Marks B, Evans PR, McMahon HT. 1999. Importance of the pleckstrin homology domain of dynamin in clathrin-mediated endocytosis. Curr Biol 9: 257-260.

Verstreken P, Koh TW, Schulze KL, Zhai RG, Hiesinger PR, Zhou Y, Mehta SQ, Cao Y, Roos J, Bellen HJ. 2003. Synaptojanin is recruited by endophilin to promote synaptic vesicle uncoating. Neuron 40: 733-748.

Verstreken P, Ohyama T, Haueter C, Habets RL, Lin YQ, Swan LE, Ly CV, Venken KJ, De Camilli P, Bellen HJ 2009. Tweek, an evolutionarily conserved protein, is required for synaptic vesicle recycling. Neuron 63: $203-$ 215.

Voglmaier SM, Kam K, Yang H, Fortin DL, Hua Z, Nicoll RA, Edwards RH. 2006. Distinct endocytic pathways control the rate and extent of synaptic vesicle protein recycling. Neuron 51: 71-84.

von Gersdorff H, Matthews G. 1994. Dynamics of synaptic vesicle fusion and membrane retrieval in synaptic terminals. Nature 367: 735-739.

von Kleist L, Stahlschmidt W, Bulut H, Gromova K, Puchkov D, Robertson MJ, MacGregor KA, Tomilin N Pechstein A, Chau N, et al. 2011. Role of the clathrin terminal domain in regulating coated pit dynamics revealed by small molecule inhibition. Cell 146: 471484.

Walther K, Krauss M, Diril MK, Lemke S, Ricotta D, Honing S, Kaiser S, Haucke V. 2001. Human stoned B interacts with AP-2 and synaptotagmin and facilitates clathrincoated vesicle uncoating. EMBO Rep 2: 634-640.

Walther K, Diril MK, Jung N, Haucke V. 2004. Functional dissection of the interactions of stonin 2 with the adaptor complex AP-2 and synaptotagmin. Proc Natl Acad Sci 101: 964-969.
Wan HI, DiAntonio A, Fetter RD, Bergstrom K, Strauss R, Goodman CS. 2000. Highwire regulates synaptic growth in Drosophila. Neuron 26: 313-329.

Wang Q, Navarro MV, Peng G, Molinelli E, Goh SL, Judson BL, Rajashankar KR, Sondermann H. 2009. Molecular mechanism of membrane constriction and tubulation mediated by the F-BAR protein Pacsin/Syndapin. Proc Natl Acad Sci 106: 12700-12705.

Weissenhorn W. 2005. Crystal structure of the endophilinA1 BAR domain. J Mol Biol 351: 653-661.

Wenk MR, Pellegrini L, Klenchin VA, Di Paolo G, Chang S, Daniell L, Arioka M, Martin TF, De Camilli P. 2001. PIP kinase $\mathrm{I} \gamma$ is the major $\mathrm{PI}(4,5) \mathrm{P}(2)$ synthesizing enzyme at the synapse. Neuron 32: 79-88.

Wienisch M, Klingauf J. 2006. Vesicular proteins exocytosed and subsequently retrieved by compensatory endocytosis are nonidentical. Nat Neurosci 9: 1019-1027.

Wu LG, Betz WJ. 1996. Nerve activity but not intracellular calcium determines the time course of endocytosis at the frog neuromuscular junction. Neuron 17: 769-779.

Wu W, Wu LG. 2007. Rapid bulk endocytosis and its kinetics of fission pore closure at a central synapse. Proc Natl Acad Sci 104: 10234-10239.

Wu W, Xu J, Wu XS, Wu LG. 2005. Activity-dependent acceleration of endocytosis at a central synapse. J Neurosci 25: $11676-11683$.

Wu XS, McNeil BD, Xu J, Fan J, Xue L, Melicoff E, Adachi R, Bai L, Wu LG. 2009. $\mathrm{Ca}^{2+}$ and calmodulin initiate all forms of endocytosis during depolarization at a nerve terminal. Nat Neurosci 12: 1003-1010.

Wu M, Huang B, Graham M, Raimondi A, Heuser JE, Zhuang X, De Camilli P. 2010. Coupling between clathrin-dependent endocytic budding and F-BAR-dependent tubulation in a cell-free system. Nat Cell Biol 12 902-908.

Wu X, Bradley MJ, Cai Y, Kummel D, De La Cruz EM, Barr FA, Reinisch KM. 2011. Insights regarding guanine nucleotide exchange from the structure of a DENN-domain protein complexed with its Rab GTPase substrate. Proc Natl Acad Sci 108: 18672-18677.

Wucherpfennig T, Wilsch-Brauninger M, Gonzalez-Gaitan M. 2003. Role of Drosophila Rab5 during endosomal trafficking at the synapse and evoked neurotransmitter release. J Cell Biol 161: 609-624.

Xing Y, Bocking T, Wolf M, Grigorieff N, Kirchhausen T, Harrison SC. 2010. Structure of clathrin coat with bound Hsc70 and auxilin: Mechanism of Hsc70-facilitated disassembly. EMBO J 29: 655-665.

Yamabhai M, Hoffman NG, Hardison NL, McPherson PS, Castagnoli L, Cesareni G, Kay BK. 1998. Intersectin, a novel adaptor protein with two Eps15 homology and five Src homology 3 domains. J Biol Chem 273: 31401 31407.

Yamashita T, Hige T, Takahashi T. 2005. Vesicle endocytosis requires dynamin-dependent GTP hydrolysis at a fast CNS synapse. Science 307: 124-127.

Yao CK, Lin YQ, Ly CV, Ohyama T, Haueter CM, Moiseenkova-Bell VY, Wensel TG, Bellen HJ. 2009. A synaptic vesicle-associated $\mathrm{Ca}^{2+}$ channel promotes endocytosis and couples exocytosis to endocytosis. Cell 138: $947-$ 960. 
Yao J, Kwon SE, Gaffaney JD, Dunning FM, Chapman ER. 2011. Uncoupling the roles of synaptotagmin I during endo- and exocytosis of synaptic vesicles. Nat Neurosci 15: 243-249.

Yim YI, Sun T, Wu LG, Raimondi A, De Camilli P, Eisenberg E, Greene LE. 2010. Endocytosis and clathrin-uncoating defects at synapses of auxilin knockout mice. Proc Natl Acad Sci 107: 4412-4417.

Zhang JZ, Davletov BA, Sudhof TC, Anderson RG. 1994. Synaptotagmin I is a high affinity receptor for clathrin AP-2: Implications for membrane recycling. Cell 78: 751-760.
Zhang B, Koh YH, Beckstead RB, Budnik V, Ganetzky B, Bellen HJ. 1998. Synaptic vesicle size and number are regulated by a clathrin adaptor protein required for endocytosis. Neuron 21: 1465-1475.

Zhang Q, Li Y, Tsien RW. 2009. The dynamic control of kissand-run and vesicular reuse probed with single nanoparticles. Science 323: 1448-1453.

Zoncu R, Perera RM, Balkin DM, Pirruccello M, Toomre D, De Camilli P. 2009. A phosphoinositide switch controls the maturation and signaling properties of APPL endosomes. Cell 136: 1110-1121. 